\title{
The Role of Intellectual Capital Information in Performance Measurement in Egyptian Governmental Universities
}

\author{
Dr. Aly Mogahed Ahmed \\ Associate Professor of Accounting \& \\ Chairman of Accounting Department \\ Faculty of Commerce \\ Kafr El-Sheikh University \\ Dr. Ayman Mohamed Sabry Nokhal \\ Lecture at Accounting Department \\ Faculty of Commerce \\ Kafr El-Sheikh University \\ Lamees Ameen Mohamed Abdulmajid \\ Demonstrator at Accounting Department \\ Faculty of Commerce \\ Kafrelshiekh University
}


The Role of Intellectual Capital Information in Performance Measurement in Egyptian Governmental Universities

\begin{abstract}
:
During the last decade the growing interest of intellectual capital has been shifted from business organizations to higher education sector and universities because they play a critical role for the development and growth of nations. So, the main purpose of this research is to investigate the importance of using intellectual capital information in evaluating the performance of the Egyptian governmental universities. For achieving this purpose, the researchers relied on judgmental sampling and 450 questionnaires were distributed on a sample consisting of a group of faculty staffs, postgraduate students, and undergraduate students from Egyptian governmental universities. The researchers received 300 valid and usable questionnaires and available for analysis. The results of the field study indicated that using intellectual capital information has a great importance in measuring and evaluating the performance in Egyptian governmental universities that could enhance the performance of universities in order to compete globally. The results also indicated that using relational capital information is the most important variable in measuring and evaluating the performance in Egyptian governmental universities.
\end{abstract}

Keywords: Intellectual Capital (IC), Performance Measurement, Universities.

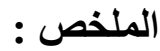

لقد تحول الاهتمام المتزايد برأس المال الفكري خلال العقد الماضي من مؤسسات

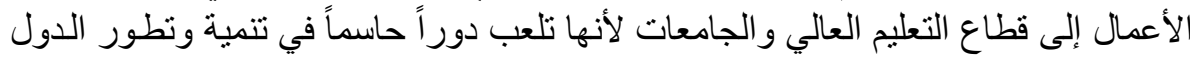

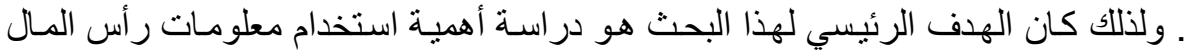

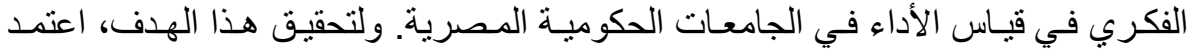

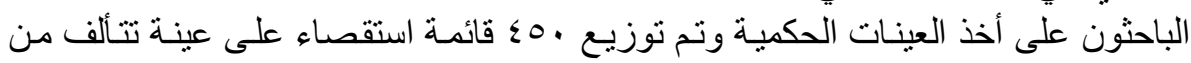

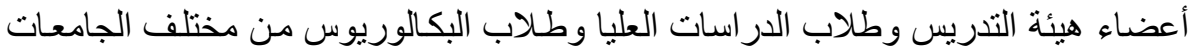

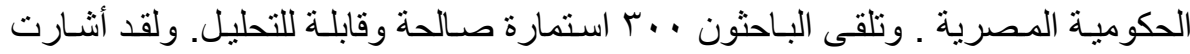

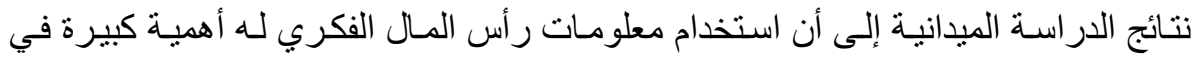

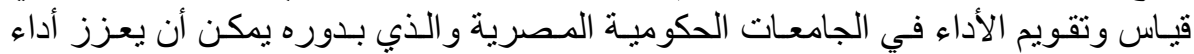

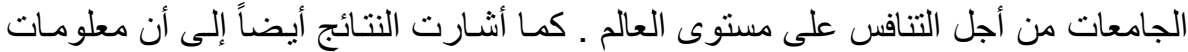

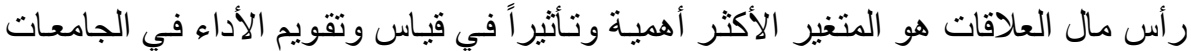

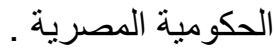

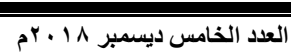




\section{General Framework}

\subsection{Introduction}

Over the past two decades, the introduction of performance measurement has been one of the most widespread international trends in the world (Spekle and Verbeeten, 2014, p.131). Performance measurement is a core activity for all organizations. So, any entity needs a robust performance measurement system to know whether its activities are performed efficiently and effectively (State Services Commission, 2008, p.3).

Performance measurement was foremost intended for the business sector but since the gap between business sector and public sector has narrowed considerably in the last decade, the interest in performance measurement in the public sector has increased among researchers and practitioners. The interest in performance measurement in public sector is also due to the evolving pressure on showing effectiveness which is experienced by public managers (Cairns et. al., 2005, p. 135).

Organizations in the public and private sectors around the world are struggling with their performance measurement systems. In particular they are finding it difficult to develop cost-effective and meaningful measures that drive performance improvement without leading to undesired negative consequences (Moullin, 2007, p.181).

Since the world is fast moving from an industrial based economy to knowledge based one, intellectual capital became a core factor in the competitiveness of a nation, and its role has been increasing not only from a national perspective, but also in terms of individual firms (Kim et al., 2006, p.29). Intellectual capital is the most important capital in any organization and it can affect the performance of the organization in all aspects (Ahmadi et al., 2012, p.896).

There is a growing interest in applying an intellectual capital approach in universities because of the main goals of universities are the production and diffusion of knowledge and their most important investments are in research and human resources (Ramirez et. al., 2013, p.27).

Recently, There are several researchers found that intellectual capital is a core factor in enhancing performance of universities; and using it is considered as a tool for performance measurement (Sharabati et al., 2013; Sharafi and Abbaspour, 2013; Shehzad et al., 2014; Awan and Saeed, 2015). 


\subsection{Research Problem}

Although Egypt has one of the largest university systems in Africa and the developing world, higher education in Egypt currently suffers from a decline in the quality and performance of education. This decline is a result of many challenges that the Egyptian system faces (Ghazal, 2012, p.19).

The main problem of the research is represented in the deficiency of the current performance measures in universities, which led to the lack of continuous follow-up and failure to properly address the weaknesses in the performance of universities, which in turn led to spacing between the performance of Egyptian governmental universities and their peers globally. This was noticed by the sharp decline in the presence of Egyptian governmental universities in the global ranking of universities such as Webometrics Ranking.

Therefore, this research suggested the use of intellectual capital information in measuring performance in Egyptian governmental universities in order to enhance their performance; this was based on the importance of the role of intellectual capital in performance improvement in many industries. Intellectual capital has become the primary resource for creating wealth and value in most industries, surpassing the contributions of traditional resources. It is also gaining importance day by day as an approach for measuring intangibles, especially in the growing context of the knowledge based economy such as universities. The role of intellectual capital is particularly relevant in universities as it adds economic value through the creation and dissemination of knowledge (Ramirez et al., 2013). Clearly, university is considered a factory of intellectual capital because universities, by nature, are knowledge-rich organizations.

Therefore, we can summarize the research problem in the following main question:

What is the importance of using intellectual capital information in measuring performance in the governmental universities in Egypt?

To answer the main research question, we should answer the following three sub-questions:

1. What is the importance of using human capital information in measuring performance in the governmental universities in Egypt?

2. What is the importance of using structural capital information in measuring performance in the governmental universities in Egypt?

3. What is the importance of using relational capital information in measuring performance in the governmental universities in Egypt?

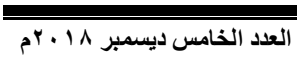




\subsection{Research Objective}

The main objective of the research is to investigate the importance of using intellectual capital information in measuring performance in governmental universities in Egypt. The main objective of this research could be achieved through the following three objectives:

1. Investigating the importance of using human capital information in measuring performance in governmental universities in Egypt.

2. Investigating the importance of using structural capital information in measuring performance in governmental universities in Egypt.

3. Investigating the importance of using relational capital information in measuring performance in governmental universities in Egypt.

\subsection{Research Importance}

The research may be significant in several aspects and it may contribute to the literature both in terms of theory and practice.

\section{Theoretical Importance}

1. The importance of the research is closely related to the importance of intellectual capital in the knowledge based economy and the importance of its role in enhancing performance and creating value for organizations and nations.

2. The importance of the research comes also from the pressures that universities are facing to enhance their performance and the lack of studies that take performance measurement of universities into account.

3. The research is also important to the literature to investigate the extent to which using intellectual capital information is important in measuring performance in universities.

\section{* Practical Importance}

1. It is anticipated that the results of this research could enhance the understanding of the importance of using intellectual capital information in measuring performance in universities.

2. It could encourage universities to consider formal implementations of intellectual capital strategies in order to maximize performance to be able to compete globally.

\subsection{Research Methodology}

In order to achieve the research objective, the researcher used the deductive and inductive approaches.

\section{Deductive Approach}

The theoretical part will depend on the deductive approach which will be used to analyze the content of the previous studies 
relevant to research; in order to build a theoretical framework about the importance of using intellectual capital information in measuring performance in governmental universities in Egypt.

\section{Inductive Approach}

The practical side will depend on the inductive approach through designing a structured questionnaire, which represents the research tool, and distributing it on a group of faculty staffs, postgraduate students, and undergraduate students from different Egyptian governmental universities in order to investigate the importance of using intellectual capital information in measuring performance in governmental universities in Egypt through testing the hypothesis of the field study.

\subsection{Research Limitations}

The research will not be exposed to intellectual capital measurement and the different ways of measuring intellectual capital. It will be limited to studying the role of using intellectual capital information in measuring performance of governmental universities in Egypt.

\subsection{Research Organization}

In order to achieve research objective, the research will be divided into the following sections

1. General Framework.

2. Literature Review

3. Performance Measurement in Universities.

4. Intellectual Capital in Universities.

5. Relationship between IC information and performance of universities

6. The field study.

7. Conclusion; Results; and Recommendations.

\section{Literature Review}

This section displays the literatures concerned with the relationship between intellectual capital information and performance in universities.

\subsection{Gonzalez-Loureiro and Teixeira, 2011:}

The researchers have discussed three main initiatives in public universities: measurement, management and disclosure of intellectual capital, but they focused on proposing a framework called performance-oriented model including IC elements, performance indicators, and the three main missions in universities: teaching, researching and the so-called third mission, transferring knowledge.

They have concluded that the proposed framework is the base to evaluate the whole dimension of the missions and goals of

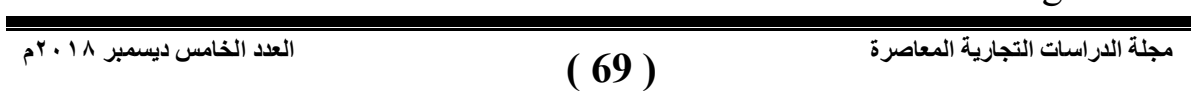


universities in the current environment: education, research and transferring functions. IC elements are the means of the university to be managed in order to achieve the adequate performance, and taking into account the mission and goals of such organization. Therefore, the proposed model is performance-oriented:

* It can help university managers fixing quantitative and qualitative objectives in each of the three missions;

It will help university managers controlling the performance on each function;

It could inform about the key IC elements that best help improving each mission;

* It can inform to stakeholders about the achievements in each function and about the overall influence of the university activities in its environment.

* This proposed framework also contributes to the overall discourse of IC in universities:

* It rationalizes the main existing initiatives by categorizing IC in the commonly accepted elements;

It includes the three dimensions of the universities' mission, while current initiatives are more focused in research. Therefore, this approach is more comprehensive while keeping it enough simple and easy to find conclusions;

Consequently, it will shed some light on the possible interactions among research, teaching and transferring functions during the value creation process in universities, by efficiently managing IC elements.

\subsection{Taleghani et al., 2011:}

The purpose of this study is measuring the significance of the relationship between intellectual capital and productivity of education of Guilan province. And to achieve this purpose the researchers conducted descriptive-analytical research with statistical society of 31 department of education in Guilan Province in Iran, they collected information about human capital, structural capital, relational capital and information of productivity in this questionnaire.

The results revealed that:

* There is a direct relationship between intellectual capital and productivity of education organizations of Guilan province. If intellectual capital increases in the organization, it has a positive

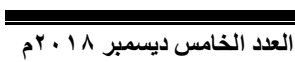


impact and meaningful effect on the productivity of the organization.

There is a direct relationship between variables of human capital, structural capital and relational capital and productivity of education organizations. Thus, if any variable of them increases, the productivity of the organization increases.

\subsection{Sharabati et al., 2013:}

The purpose of this study is to investigate the influence of intellectual capital on the performance of the Middle East University (MEU) through examining the managers' perceptions regarding significance and potential use of IC indicators to leverage MEU's performance. This study surveyed academic and administrative staffs, as well as, Master and Bachelor students at MEU. Practical data were used in the empirical analysis collected from 167 participants out of 3217 elements, by means of a questionnaire.

The results showed that the participants were almost similar in their preferences regarding $\mathrm{HC}, \mathrm{SC}$ and $\mathrm{RC}$, and they believe that MEU has low implementation regarding these three variables. The results also indicated a positive significant relationship between IC and MEU's performance. However, respondents believe that the RC has the highest effect on performance, followed by $\mathrm{HC}$, while they do not believe that SC affects performance. Furthermore, empirical results indicated that there are strong inter-relationships and interactions among the three components of IC.

\subsection{Shojaie and Barani, 2013:}

Shojaie and Barani tried to investigate the effect of application of intellectual capital on performance of faculty of humanities of Islamic Azad University of Ghaemshahr Branch, Iran. They divided intellectual capital into three main elements: human capital, structural capital and relational capital and each including 10 items. They based on questionnaire in their research and the Statistical Society was professors of Faculty of human science in the University of Ghaemshahr and 103 questionnaires were distributed and only 87 questionnaires were returned.

The results revealed that there is a significant relationship between human capital and performance and also between relational capital and performance. And by investigating the performance of faculty of humanities of Islamic Azad University, they found that the priority of elements of intellectual capital are as follow: 1) relational capital, 2) structural capital and 3) human capital that is because there are more issues such as communication with students, getting feedback and trying to meet the needs of their students those are 
belong to relational capital and later focused on issues such as intellectual property management, work processes and procedures, management of information systems those are belong to structural capital and finally focused on human capital that includes knowledge of scientists and university researchers, students and skills and competencies of staff. Therefore they proposed suggestions through the application of intellectual capital based on priorities to solve these issues and improve performance of the faculty.

\subsection{Rashid and Alzaidi, 2014:}

This study examined the role of intellectual capital in achieving superior university performance. It attempted to provide theoretical framework for some of what writers and researchers had introduced about its variables, a practical analysis of the opinions of (34) educational leaderships in a sample faculties of Al-Qadisiya university. Intellectual capital is the independent variable and includes three components (human capital, structural capital, and relational capital), while superior university performance is the dependent variable and had been expressed through five indicators of business results based on Baldrige program for performance excellence in education version 2011- 2012. The study used a questionnaire as a main tool for measuring its variables.

The researchers concluded that:

There is a direct relationship between intellectual capital components and superior university performance, so the university needs continuous improvement of these components to achieve superior results.

Intellectual capital and its three components have a great impact on the university's superior results in the field of focusing on workforce.

\subsection{Shehzad et al., 2014:}

The main purpose of this research is to explore the role and relationship of intellectual capital and its three components on the performance and efficient working of universities in Pakistan. Education sector especially universities were selected because it plays a critical role for the development and growth of knowledge intensive sector. So in this research 3 components of intellectual capital - human capital, structural capital and relational capital - were taken as independent variables and institution's performance is taken as dependent variable. A structured questionnaire is adopted from the past research studies and 800 responses have been collected from various public and private university students in Pakistan.

The results showed that:

مجلة اللراسات التجارية المعاصرة


1. All three types of intellectual capital are linked directly with the performance of universities. But performance of universities is more influenced by human capital as compared to structural and relational capital. As human capital includes employees, staff of the university so they are the valuable assets for the organization. And if they are managed properly, they can surely lead the organization toward success. That's why human capital has more positive influence on the performance of universities.

2. Structural capital provides support for a university human capital. As it includes rules and regulations, processes, systems and programs and research developments of institution so it also has a positive influence on institution's performance. If an institution has proper rules and regulations, comprehensive research development plans, then it is obvious that performance of the organization is positively affected.

3. Relational capital has a little effect on institution performance. An institution's relation with other institutions and with outsiders has no strong impact on universities performance as compared to human and structural capital. Human and structural capital has more positive influence on the performance of universities.

4. So it is concluded that although all the three components of IC has a positive influence on the performance of universities but human capital is more prominent among all of them. Structural capital also has strong influence on performance but less than human capital. And relational capital is on last number regarding its influence on the performance of universities.

\subsection{Awan and Saeed, 2015:}

Awan and Saeed tried to identify the impact of intellectual capital on research performance of universities in Pakistan. They also analyzed the concept of intellectual capital, its importance for higher educational institutions and its impact on their working environment and performance. They have selected two universities and taken a sample of 200 employees of these Universities: 150 academic and 50 non-academics. The data was collected through a structured questionnaire by conducting face-to-face interview.

The results of their study revealed that intellectual capital has a significant impact on research performance of the two universities in general. In terms of impact human capital was ranked first and most important, followed by structural capital while relational capital ranked last among the components. In other words, human capital has greater contribution and influence on the performance of these two 
Universities. The evidence shows that the universities' community can be effectively performing their core activities and duties if they utilize and manage intellectual capital in a proper way and this can only be done when they are aware of the benefits and relevant incentives.

\subsection{Evaluation of the Previous Studies}

1. Many literatures from different environments concerned with studying the relationship between intellectual capital and performance in universities.

2. Most literatures divided intellectual capital into three main components: human capital, structural capital, and relational capital.

3. They all used questionnaire as instrument for gathering information but they surveyed different populations from professors, workers, or students.

4. They all concluded that there is a direct and significant relationship between intellectual capital and performance of universities, but they did not agree about the most important component of intellectual capital affecting performance, and the following table displays the descending order of intellectual capital components affecting performance according to each study:

\begin{tabular}{|c|c|}
\hline Study & $\begin{array}{l}\text { The descending order of intellectual } \\
\text { capital components affecting performance }\end{array}$ \\
\hline $\begin{array}{l}\text { Sharabati et al., } \\
2013\end{array}$ & $\begin{array}{l}\text { 1. Relational capital } \\
\text { 2. Human capital } \\
\text { 3. Structural capital }\end{array}$ \\
\hline $\begin{array}{l}\text { Shojaie and Barani, } \\
2013\end{array}$ & $\begin{array}{l}\text { 1. Relational capital } \\
\text { 2. Structural capital } \\
\text { 3. Human capital }\end{array}$ \\
\hline $\begin{array}{l}\text { Shezhad et al., } \\
2014\end{array}$ & $\begin{array}{ll}\text { 1. } & \text { Human capital } \\
\text { 2. } & \text { Structural capital } \\
\text { 3. } & \text { Relational capital }\end{array}$ \\
\hline $\begin{array}{l}\text { Awan and Saeed, } \\
2015\end{array}$ & $\begin{array}{ll}\text { 1. } & \text { Human capital } \\
\text { 2. } & \text { Structural capital } \\
\text { 3. } & \text { Relational capital }\end{array}$ \\
\hline
\end{tabular}

5. As a result of the direct and significant relationship between intellectual capital and performance in universities, many different benefits could brought up to universities such as raising performance, gaining a competitive advantage, increasing the efficiency and quality of the university, etc. 
6. The Egyptian environment has many literature concerned with the relationship between intellectual capital and performance in different business organizations but it has a scarcity in the researches concerned with the relationship between intellectual capital and performance in public sector especially in governmental universities.

\section{Performance Measurement in Universities}

Performance measurement is a core activity for all organizations including universities. Therefore, this section introduces some definitions of performance measurement and some problems facing universities in measuring performance.

\subsection{Performance Measurement Definition}

Performance measurement was foremost intended for the business sector but since the gap between business sector and public sector has narrowed considerably in the last decade, the interest in performance measurement in the public sector has increased among researchers and practioners (Cairns et. al., 2005, p. 135).

Performance measurement is generally defined as regular measurement of outcomes and results, which generates reliable data on the effectiveness and efficiency of programs. Performance measurement refers to the set of actions put in place to determine the extent to which an organization is achieving its pre-determined targets (Alboushra et al., 2015, p.11). The researcher defined performance measurement as the process of assessing and evaluating the proficiency of organizational activities performed to provide final product or service to stakeholders through comparing actual results with desired or predetermined ones. It can also be an effective tool for controlling and improving performance of organizations.

\subsection{Performance Measurement Problems}

The use of performance measurement systems in organizations in the developing countries is steadily increasing especially in Africa (De Waal, 2007; Karuhanga, 2010). Performance measurement systems are supposed to create incentives that help to align individual goals with the objectives of the organization, provide valuable feedback information on the progress towards these objectives, and form the basis for internal and external accountability (spekle and verbeeten, 2014, p.132).

There are many different ways used globally to measure performance of universities such as Performance Measurement Matrix (PMM), Balance Scorecard (BSC), Performance Pyramid Model (also known as SMART - Strategic Measurement and Reporting مجلة الدراسات التجارية المعاصرة: 
Technique), Performance Prism (PP), Public Service Value Model (PSV), and Common Assessment Framework (CAF). But the most widespread performance measurement model in Egyptian universities is the BSC.

Although BSC is the most common model for performance measurement in Egyptian governmental universities, but it is not activated in a large number of universities. This is due to some of problems facing universities in the performance measurement process. These problems could be summarized as follow:

1. Lack of sufficient financial resources; which might result in a delay or even postponement of the performance measurement implementation, because funding is a major obstacle to achieve some objectives of universities, such as improving the learning environment, staff development and training, students' extracurricular activities, and many other activities (De Waal \& Counet, 2008; Ofori \& Atiogbe, 2011).

2. Lack of motivation and low morale; the majority of employees have a negative attitude towards work because there are no rewards for good performance. Individual remuneration is not linked to performance but to seniority and job position, this can greatly affect implementation because much as the person earning a lot can have the motivation to dedicate all his time to implementing university policies. This kind of 'unfairness' discourages hard work (Karuhanga, 2010).

3. Goal diversity and ambiguity; which are a common phenomenon in a wide range of universities and that constitutes a major problem in measuring performance (Wang, 2010). This means that universities have their targets and objectives, but they don't have clear action plans to meet these objectives, and it is not clear who is responsible for achieving them. Moreover, the institutional goals sometimes conflict with personal goals (Alboushra, 2015, p.14).

4. Strategy implementation; the strategic plan is formulated but never implemented. Implementation of strategy is a daunting task. Most of the employees are not aware of the major goals of the university and the administration is preoccupied with administrative work, this constrains implementation. There is no feedback on performance and there is no evaluation (Karuhanga, 2010).

5. Resistance to performance measurement; the resistance to any new performance measurement system may come from the lack of understanding, insufficient training, and sometimes, the fear of unknown (Karuhanga, 2010; Alboushra, 2015). 
In addition to the performance measurement problems mentioned above, there are also some weaknesses of BSC (Striteska and Spickova, 2012) such as:

Too few measures (two or three) per perspective; a good balanced scorecard should have an appropriate mix of outcomes (lagging indicators) and performance drivers (leading indicators) of the company's strategy. This may cause failing to obtain a balance between leading and lagging indicators.

* Too many indicators; this may lose focus and cannot find any linkage between indicators.

It does not express the interests of all stakeholders

The lack of long-term commitment and leadership for management

The lack of employee awareness and the difficulty to communicate information to all employees.

It is constructed as a controlling tool rather than an improvement tool.

Furthermore, studies concerned with performance measurement of universities in Egypt are still at an early stage. And applying the concept of performance measurement in practice is very limited. However, in many countries in the world measuring performance of universities has become a practice adopted by law, such as the USA, Canada, UK, Australia, New Zealand, and Netherlands, and China began introducing a performance measurement system since the $80 \mathrm{~s}$, which has been improved over the years (Mihaiu, 2014).

For all problems mentioned above about the implementation of performance measurement in Egyptian governmental universities, we try in this research to find a solution for these problems by using intellectual capital information in measuring performance in universities.

\section{Intellectual Capital in Universities}

Since the world is fast moving from an industrial based economy to knowledge based one, intellectual capital became a core factor in the competitiveness of a nation, and its role has been increasing not only from a national perspective, but also in terms of individual organizations especially universities (Kim et al., 2006) because they are considered a factory of intellectual capital.

\subsection{Intellectual Capital Definition}

Although intellectual Capital has been defined in many ways and by a vast number of researchers, there is neither clear cut 
definition for it, nor an agreement on its classification (Sharabati et al., 2013 , p. 567). Intellectual capital is the knowledge assets that can be converted into value. It is a matter of creating and supporting connectivity between sets of expertise, experience and competences inside and outside organization (Cabrita and Bontis, 2008). Saleh (2009) defined IC as a group of unique knowledgeable assets that is based on creative human minds, work requirements and systems, and the customer relations, which lead to continuous production of new ideas and methods and achieve value added to the organization and support its competitive abilities. And the researcher defined it as the hidden intangible assets that exist in any organization which appear only when the exploitation and development of its employees' knowledge, capabilities, skills, expertise, competencies, and relations, and that may be essential for creating value, enhancing performance and therefore achieving competitive advantage to the organization.

\subsection{Intellectual Capital Structure}

There is no agreement among researchers about a unique intellectual capital structure, but most researchers use three common main components, with different names, in intellectual capital structure, and the elements/indicators included in each component differ according to the sector being studied. The following shape summarizes most intellectual capital structures:

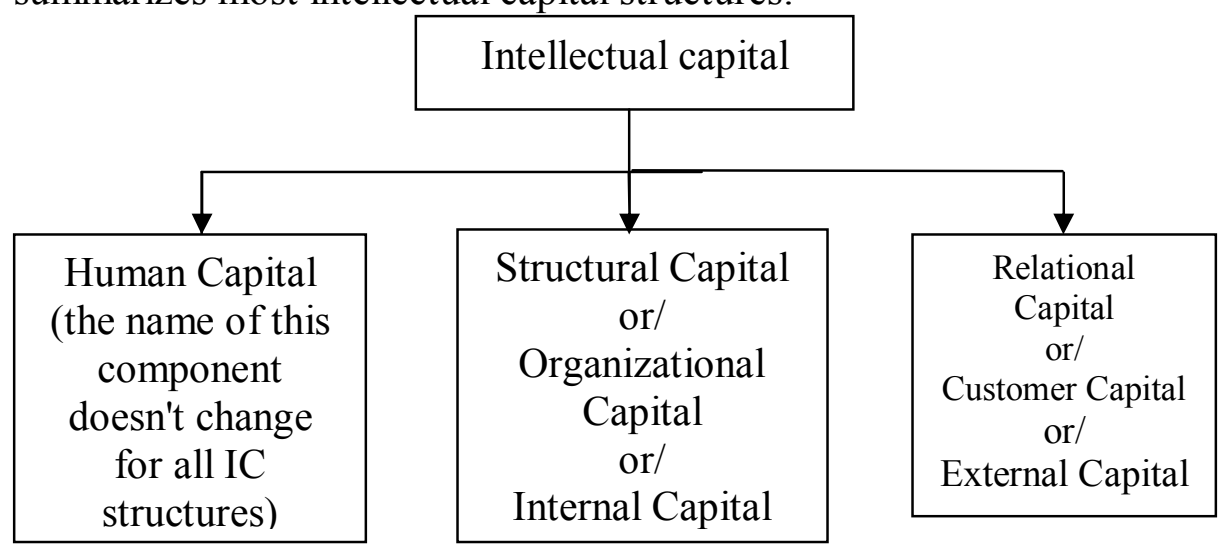

Some researchers rely only on these three components of intellectual capital, but others add one or two more components in IC structure such as innovation capital, social capital, technological capital, etc.

This study supports literatures and depends on the following IC structure in the context of universities: 


\begin{tabular}{|c|c|}
\hline $\begin{array}{c}\text { IC } \\
\text { Structure }\end{array}$ & Definition and Characteristics \\
\hline & $\begin{array}{l}\text { Human capital represents the stock of staff } \\
\text { knowledge in an organization. } \\
\text { Human capital is the foundation of intellectual } \\
\text { capital and without it, intellectual capital cannot be } \\
\text { implemented. } \\
\text { Human capital belongs to the organization staff. } \\
\text { Human capital is not owned by organizations. It } \\
\text { is taken out from organizations with the departure of } \\
\text { Orgayees. } \\
\text { outflow by converting it to other kinds of capital } \\
\text { (structural and relational capital) (Ahmadi et al., 2012, } \\
\text { knom). } \\
\text { knowledge, skills, expertise, experience, abilities, } \\
\text { education, learning, training, tolerance, motivation, loyalty, } \\
\text { satisfaction, ability to solve problems (Arafat, 2011, p.40). }\end{array}$ \\
\hline $\begin{array}{c}\text { Structural } \\
\text { Capital }\end{array}$ & $\begin{array}{l}\text { Structural capital refers to the intangible } \\
\text { resources that are found in the organization itself. } \\
\text { Structural capital also remains when academic } \\
\text { staff, administrative staff, and students leave. } \\
\text { Structural capital is not protected by the law. } \\
\text { Structural capital includes processes, strategies, } \\
\text { procedures, networks, concepts, systems, databases, } \\
\text { organizational charts, research projects, and research } \\
\text { infrastructure (Arafat, 2011, p.40). }\end{array}$ \\
\hline $\begin{array}{c}\text { Relational } \\
\text { Capital }\end{array}$ & $\begin{array}{l}\text { Relational capital is the ability to establish and } \\
\text { use relationships on the basis of cooperation between } \\
\text { the entities. } \\
\text { Relational capital cannot be found without the } \\
\text { existence of human capital in the organization. } \\
\text { Relational capital is shaped by human capital. }\end{array}$ \\
\hline
\end{tabular}


1 Relational capital is established as a result of mutual trust, openness, transparency, social bonds and common values of the entities

1 Relational capital includes relations with different types of stakeholders such as students, graduates, public, governments, and other organizations.

\subsection{The Importance of Intellectual Capital for Universities}

There is a growing interest in applying an intellectual capital approach in universities, since the main goals of universities are the production and diffusion of knowledge and their most important investments are in research and human resources (Ramirez et. al., 2013, p.27).

Nowadays, from making wealth aspect, resources included in intellectual capital of universities become more important in comparison with other resources. One of the major assets of universities is intellectual capital, since it promotes competitive advantages that are the base of value generation and enhancing performance (Ramirez et. al., 2013, p.27).

Universities are critical institutional actor for national innovation, where IC is an asset that can contribute to society. IC has become of prime importance in universities, because knowledge is their main output and input. The most important output of universities is knowledge, incorporated in new research results, publications and well educated students. Their most valuable resources also include their teachers, researchers, administration and service staff, university governors and students, with all their organizational relationships and routines. It is true to say then that universities' input and output are largely intangible (Canibano and Sanchez, 2008, p. 9). Higher education institutions are, therefore, an ideal framework for the application of the ideas related to IC theory (Ramirez and Gordillo, 2014, p. 174).

\subsection{Intellectual Capital Reporting for Universities}

The presentation of information about intellectual capital has now become of prime importance in institutions of higher education, principally because knowledge is the main input and output of these institutions.

Below are some of the reasons why it is a major necessity for universities to start including information of IC in their current accounting systems (Ramirez et. al., 2016, p.178):

As organizations which are mainly financed by public funding, universities are also facing an increased demand by citizens for

مجلة الدراسات التجارية المعاصرةة


transparency regarding the use of those funds. This call for public accountability requires the disclosure about the social and economic outcomes of universities.

Universities are now facing growing competition due to lower funding, which puts them under greater pressure to communicate their results. External agencies and governments are supervising academic outputs and linking public funding to research results through new performance and funding agreements. Accordingly, IC reporting can facilitate the presentation of results, which could help to attract funds from other lower performing competitors. So, IC reporting can enhance competitiveness.

The greater independence of universities regarding their organization, management and budget distribution requires greater social responsibility which will lead universities to prepare accounting information to report to society as well as to facilitate and satisfy the information needs of participants in the university itself.

The increasing cooperation between universities and firms has resulted in the demand for similar processes of evaluation for both organizations. Accordingly, universities would have to implement new management and reporting systems, which necessarily incorporate intangibles. Also, it strengthens the links between universities and the business environment by using a common language. Therefore, implementing IC reports to diffuse information could have a positive impact on university-industry collaborations and third mission activities.

* The IC reports would allow comparing different rating systems from other universities.

* In addition to the purpose of delivering information for the public authority, some authors argue that evaluations should also deliver information for the general public and thus meet the demand for social accountability (Leitner, 2002, p.8).

Despite the increased pressure on universities to render a broader account of their activities, most countries do not require universities to present information on intellectual capital. The only exception is Austria, where universities have been obliged to present an intellectual capital report since January 2007 (Leitner, 2002, p.5).

\section{The Relationship between IC Information and Performance of Universities}

The importance of IC is highlighted in the era of knowledgebased economies, where IC, instead of traditional tangible assets, is 
the dominant value driver for any organization. Although, IC is still not being sufficiently implemented in Egyptian universities, previous literatures from other countries have shown that IC plays an important role and have a significant impact on performance of universities (Ramirez et al., 2007).

Many practitioners, academicians and researchers (Taleghani et al., 2011; Lu, 2012; Wu et al., 2012; Sharabati et al., 2013; Shehzad et al., 2014; Awan and Saeed, 2015) consider intellectual capital as a key determinant to enhance value creation and organizational performance of universities.

\section{The Field Study \\ 6.1 Research Objective}

This study aims to investigate the importance of using intellectual capital information in measuring performance in governmental universities in Egypt to enhance performance of the universities. The main objective of this study could be achieved through the following sub-objectives:

1. Investigating the importance of using human capital information in measuring performance in governmental universities in Egypt.

2. Investigating the importance of using structural capital information in measuring performance in governmental universities in Egypt.

3. Investigating the importance of using relational capital information in measuring performance in governmental universities in Egypt.

\subsection{Research Hypotheses}

This research attempted to investigate the following main hypothesis:

Using intellectual capital information has a significant importance in measuring performance in governmental universities in Egypt.

The main hypothesis can be divided into three sub- hypotheses:

1. Using human capital information has a significant importance in measuring performance in governmental universities in Egypt.

2. Using structural capital information has a significant importance in measuring performance in governmental universities in Egypt.

3. Using relational capital information has a significant importance in measuring performance in governmental universities in Egypt. 


\subsection{Population and Sample} follow:

The population in this research consists of 3 categories as

1. Faculty staffs

2. Postgraduate students

3. Undergraduate students

The researcher relied on judgmental sampling in selecting the sample of this study. Accordingly, the study sample includes a number of faculty staffs, postgraduate students, and undergraduate students from Egyptian governmental universities. The researcher relied on two methods in distributing questionnaires: electronic and manual.

\subsubsection{Sample Categories}

According to the study population, there are three categories included in the sample. The following table demonstrates sample categories, number of manual questionnaires sent, number of received and excluded questionnaires, number of electronic questionnaires, and questionnaires subjected to statistical analysis.

Table ( 1 ) : Sample Categories

\begin{tabular}{|c|c|c|c|c|c|c|c|}
\hline 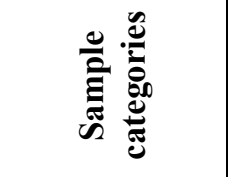 & $\begin{array}{l}\dot{\theta} \\
\dot{\theta} \\
\dot{\theta} \\
\dot{z}\end{array}$ & 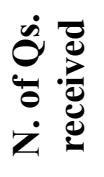 & 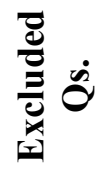 & $\dot{\vec{d}}$ & $\underset{\dot{\theta}}{\dot{\theta}}$ & 苞 & $\partial^{\theta}$ \\
\hline $\begin{array}{l}\text { Faculty } \\
\text { Staff }\end{array}$ & 250 & 189 & 14 & 175 & 65 & 240 & $80 \%$ \\
\hline $\begin{array}{c}\text { Postgraduate } \\
\text { students }\end{array}$ & 100 & 32 & 9 & 23 & 13 & 36 & $12 \%$ \\
\hline $\begin{array}{c}\text { Undergradua } \\
\text { te students }\end{array}$ & 100 & 37 & 20 & 17 & 7 & 24 & $8 \%$ \\
\hline Total & 450 & 258 & 43 & 215 & 85 & 300 & $100 \%$ \\
\hline
\end{tabular}

From table (1) we can find that faculty staff represents $80 \%$ of the sample size, while postgraduate students and undergraduate students represent together $20 \%$ of the sample size. This indicates that sample size of the second and third categories is very small comparing to sample size of the faculty staff, therefore the researcher didn't differentiate between the three categories in the statistical analysis.

\subsubsection{Scientific Qualification of Sample Members}

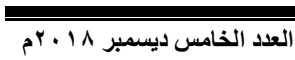


The following table demonstrates the characteristics of the study sample according to scientific qualifications. The collected data in table (2) shows that $108(36 \%)$ of the respondents hold a bachelor's degree (BSc) (knowing that undergraduate students were included in this category), $9(3 \%)$ respondents hold a diploma, $127(42.3 \%)$ respondents hold a master's degree (MSc), and 56 (18.7\%) respondents hold a $\mathrm{PhD}$. Based on these results, we find that there is a diversity of scientific qualifications of the respondents.

Table ( 2 ) : Scientific Qualifications

\begin{tabular}{|c|c|c|}
\hline Scientific Qualifications & N. of Respondents & Percentage \\
\hline BSc & 108 & $36 \%$ \\
\hline Diploma & 9 & $3 \%$ \\
\hline MSc & 127 & $42.3 \%$ \\
\hline PhD & 56 & $18.7 \%$ \\
\hline Total & $\mathbf{3 0 0}$ & $\mathbf{1 0 0 \%}$ \\
\hline \hline
\end{tabular}

\subsubsection{Job Experience of Sample Members}

The following table (3) demonstrates the characteristics of the study sample according to years of experience. The table shows that the sample is divided into 4 categories according to job experience as follow:

Table ( 3 ) : Job Experience

\begin{tabular}{|c|c|c|}
\hline Job Experience & $\begin{array}{c}\text { N. of } \\
\text { Respondents }\end{array}$ & Percentage \\
\hline \hline Less than 5 years & 64 & $21.3 \%$ \\
\hline From 5 years up to 10 years & 127 & $42.3 \%$ \\
\hline From 10 years up to 20 years & 68 & $22.7 \%$ \\
\hline Over 20 years & 41 & $13.7 \%$ \\
\hline \hline Total & $\mathbf{3 0 0}$ & $\mathbf{1 0 0 \%}$ \\
\hline
\end{tabular}

Table (3) indicates that the largest part of the sample is represented by respondents whose job experience from 5 years to 10 years $(42.3 \%)$; followed by respondents whose job experience from 10 years to 20 years $(22.7 \%)$; then, respondents whose job experience less than 5 years $(21.3 \%)$; and finally $13.7 \%$ of respondents have job experience more than 20 years.

\subsection{Research Tool}

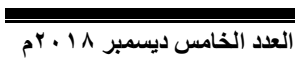


In this study, the researcher relied on the questionnaire as a tool to collect necessary data to achieve the overall objective of the study. The researcher also tried to be as precise as possible in formulating the questions of the questionnaire through the following points:

Clarifying some terms related to the research topic.

Designing the questionnaire according to the five point likert scale to record the view of respondents about the questions of the questionnaire.

\begin{tabular}{|c|c|c|c|c|c|}
\hline Category & $\begin{array}{c}\text { Very } \\
\text { Important }\end{array}$ & Important & Neutral & $\begin{array}{c}\text { Low } \\
\text { Importance }\end{array}$ & $\begin{array}{c}\text { Not } \\
\text { Important }\end{array}$ \\
\hline Degree & 5 & 4 & 3 & 2 & 1 \\
\hline
\end{tabular}

* Obtaining some general information from the members of the sample about job, scientific qualifications and years of experience.

* The researcher relied heavily on past research studies in formulating the questions of the questionnaire.

* The researcher also used some phrases taken from National Academic Reference Standards (NARS) in formulating the questions of the questionnaire, because she thinks that there is a close relation between the study topic and NARS.

\subsection{Data Encoding}

The questions of the questionnaire were coded by the following symbols to facilitate statistical analysis process:

$\mathrm{HC} 1 \ldots . . . \mathrm{HC} 35$ : are codes for questions of the first sub-hypothesis. SC 1 ..... SC 20: are codes for questions of the second subhypothesis.

RC 1...... RC 10: are codes for questions of the third sub-hypothesis. D 1: What is your opinion about the importance of obligating Egyptian governmental universities to disclose their intellectual capital information?

D 2: Will this disclosure affect the performance measurement process?

D 3: Will this disclosure contribute in improving the performance of universities?

\subsection{Questionnaire Pilot Testing}

The researcher conducted a pilot study in order to pre-test the questionnaire. The pilot study aims to enhance the questionnaire in order to make sure that respondents answer the questions smoothly without any problems. It also used to evaluate the questions' reliability and validity. And based on the results of the pilot study, the questionnaire may be modified. 
So, the researcher conducted a pilot study through distributing 80 copies of the questionnaire to faculty members, and only 60 were returned and tested for reliability and validity.

\subsubsection{Reliability Test}

Based on the pilot study, Cronbach's alpha was calculated on a sample of 60 questionnaires, and table (4) below shows Cronbach's alpha value of the variables used in this study.

Table ( 4 ) : Cronbach's Alpha Test Results

Case Processing Summary

\begin{tabular}{|cc|c|c|}
\hline & & $\mathrm{N}$ & $\%$ \\
\hline Cases & Valid & 60 & 100.0 \\
& Excluded $^{\mathrm{a}}$ & 0 & .0 \\
& Total & 60 & 100.0 \\
\hline
\end{tabular}

Reliability Statistics

\begin{tabular}{|c|c|}
\hline $\begin{array}{c}\text { Cronbach's } \\
\text { Alpha }\end{array}$ & N of Items \\
\hline .954 & 65 \\
\hline
\end{tabular}

a. Listwise deletion based on all variables in the procedure.

Table (4) shows that Cronbach's Alpha equals 0.954 that is more than 0.7 , which indicates a good reliability for all variables and a high degree of internal consistency for the questionnaire.

\subsubsection{Validity Test}

The validity of the questionnaire refers to the extent to which an instrument measures what it is supposed to measure (Bryman and Bell, 2007). The average variance of variables is used to test the validity of the questionnaire. The following table (6-5) shows the average variance of the three variables of the study and the total average variance.

Table ( 5 ) : Average Variance of Variables (Correlations)

\begin{tabular}{|lc|c|c|c|c|}
\hline & & av_x1 & av_x2 & av_x3 & av_total \\
\hline av_x1 & Pearson Correlation & 1 & $.721^{* * *}$ & $.675^{* * *}$ & $.885^{* *}$ \\
& Sig. (2-tailed) & & .000 & .000 & .000 \\
& N & 300 & 300 & 300 & 300 \\
\hline av_x2 & Pearson Correlation & $.721^{* *}$ & 1 & $.739^{* *}$ & $.911^{* *}$ \\
& Sig. (2-tailed) & .000 & & .000 & .000 \\
& N & 300 & 300 & 300 & 300 \\
\hline av_x3 & Pearson Correlation & $.675^{* *}$ & $.739^{* *}$ & 1 & $.900^{* *}$
\end{tabular}




\begin{tabular}{|cc|c|c|c|c|}
\hline & Sig. (2-tailed) & .000 & .000 & & .000 \\
& $\mathrm{~N}$ & 300 & 300 & 300 & 300 \\
\hline av_tota & Pearson Correlation & $.885^{* *}$ & $.911^{* *}$ & $.900^{* *}$ & 1 \\
1 & Sig. (2-tailed) & .000 & .000 & .000 & \\
& $\mathrm{~N}$ & 300 & 300 & 300 & 300 \\
\hline
\end{tabular}

** Correlation is significant at the 0.01 level (2-tailed).

From table (5), we can find that the average variance of the three variables and the total average variance, all are greater than 0.5 . This means that correlation between variables is strongly found and also indicates that the questionnaire has good construct validity.

After conducting reliability and validity tests, the results conclude that the questionnaire has a high degree of internal consistency as well as reliability; the results also indicate that the correlation between items in each variable is sufficiently strong, as well as the correlation between the three variables is very strong, therefore the questionnaire was distributed to the remaining sample.

\subsection{Normality Distribution Test}

Normality distribution tests are used to determine whether a data set is normally distributed, or not. Based on the results of that test, the type of statistical methods used is determined (parametric or nonparametric).

Data is tested for normality by using Kolmogorov-Smirnov (K-S) test according to the following statistical hypothesis:

$\mathrm{H}_{0}$ : Data follows normal distribution

$\mathrm{H}_{1}$ : Data does not follow normal distribution

If Sig. is more than $\alpha=0.05$; data is normally distributed, and if Sig. is less than $\alpha=0.05$; data is not normally distributed.

By conducting the normality test for the research data, the results indicate that Sig. for all variables is less than $\alpha=0.05$; therefore data is not normally distributed and the null hypothesis is rejected. Therefore, the researcher relied on nonparametric tests in the statistical analysis.

\subsection{Statistical Analysis and Testing Hypotheses}

The collected data were analyzed by using Statistical Package for Social Science (SPSS) version 21. The researcher tested the hypotheses by using three methods of statistical analysis as follow:

Analysis of Ratios

* Chi-Square Test

* Friedman Test

\subsubsection{Testing the First Sub-Hypothesis}

The first sub-hypothesis is formulated in the null and alternative forms as follow:

مجلة اللراسات التجارية المعاصرة


$\mathbf{H}_{\mathbf{0}}$ : Using human capital information is not important in measuring performance in governmental universities in Egypt.

$\mathbf{H}_{1}$ : Using human capital information has a significant importance in measuring performance in governmental universities in Egypt.

\subsubsection{Analysis of Ratios}

Table (6) shows the results of frequencies, percentages, means, and standard deviations for phrases from 1 to 35 in the questionnaire.

Table ( 6 ) : Frequencies, Percentages, Means, and Standard Deviations

\begin{tabular}{|c|c|c|c|c|c|c|c|c|c|}
\hline Item & 1 & 2 & 3 & 4 & 5 & Total & Mean & $\begin{array}{c}\text { Std. } \\
\text { Devia } \\
\text { tion }\end{array}$ & $\begin{array}{c}\text { General } \\
\text { Trend }\end{array}$ \\
\hline \multirow{2}{*}{$\mathrm{HC} 1$} & 0 & 0 & 2 & 85 & 213 & 300 & \multirow{2}{*}{4.70} & \multirow{2}{*}{.472} & \multirow{2}{*}{$\begin{array}{l}\text { Very } \\
\text { important }\end{array}$} \\
\hline & 0 & 0 & $0.7 \%$ & $28.3 \%$ & $71 \%$ & $100 \%$ & & & \\
\hline \multirow{2}{*}{$\mathrm{HC} 2$} & 0 & 0 & 1 & 94 & 205 & 300 & \multirow{2}{*}{4.68} & \multirow{2}{*}{.474} & \multirow{2}{*}{$\begin{array}{c}\text { Very } \\
\text { important }\end{array}$} \\
\hline & 0 & 0 & $0.3 \%$ & $31.3 \%$ & $68.3 \%$ & $100 \%$ & & & \\
\hline \multirow{2}{*}{$\mathrm{HC} 3$} & 1 & 1 & 2 & 97 & 199 & 300 & \multirow{2}{*}{4.64} & \multirow{2}{*}{.552} & \multirow{2}{*}{$\begin{array}{c}\text { Very } \\
\text { important }\end{array}$} \\
\hline & $0.3 \%$ & $0.3 \%$ & $0.7 \%$ & $32.3 \%$ & $66.3 \%$ & $100 \%$ & & & \\
\hline \multirow{2}{*}{$\mathrm{HC} 4$} & 0 & 5 & 12 & 135 & 148 & 300 & \multirow{2}{*}{4.42} & \multirow{2}{*}{.652} & \multirow{2}{*}{$\begin{array}{c}\text { Very } \\
\text { important }\end{array}$} \\
\hline & 0 & $1.7 \%$ & $4 \%$ & $45 \%$ & $49.3 \%$ & $100 \%$ & & & \\
\hline \multirow{2}{*}{$\mathrm{HC} 5$} & 0 & 1 & 21 & 133 & 145 & 300 & \multirow{2}{*}{4.41} & \multirow{2}{*}{.635} & \multirow{2}{*}{$\begin{array}{l}\text { Very } \\
\text { important }\end{array}$} \\
\hline & 0 & $0.3 \%$ & $7 \%$ & $44.3 \%$ & $48.3 \%$ & $100 \%$ & & & \\
\hline \multirow{2}{*}{ HC 6} & 0 & 0 & 9 & 93 & 198 & 300 & \multirow{2}{*}{4.63} & \multirow{2}{*}{.542} & \multirow{2}{*}{$\begin{array}{c}\text { Very } \\
\text { important }\end{array}$} \\
\hline & 0 & 0 & $3 \%$ & $31 \%$ & $66 \%$ & $100 \%$ & & & \\
\hline \multirow{2}{*}{$\mathrm{HC} 7$} & 0 & 1 & 4 & 90 & 205 & 300 & \multirow{2}{*}{4.66} & \multirow{2}{*}{.520} & \multirow{2}{*}{$\begin{array}{l}\text { Very } \\
\text { important }\end{array}$} \\
\hline & 0 & $0.3 \%$ & $1.3 \%$ & $30 \%$ & $68.3 \%$ & $100 \%$ & & & \\
\hline \multirow{2}{*}{$\mathrm{HC} 8$} & 0 & 0 & 6 & 94 & 200 & 300 & \multirow{2}{*}{4.65} & 510 & Ver \\
\hline & 0 & 0 & $2 \%$ & $31.3 \%$ & $66.7 \%$ & $100 \%$ & & .019 & \\
\hline HC 0 & 2 & 6 & 39 & 129 & 124 & 300 & 422 & 707 & Imp \\
\hline & $0.7 \%$ & $2 \%$ & $13 \%$ & $43 \%$ & $41.3 \%$ & $100 \%$ & 4.22 & 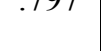 & important \\
\hline & 1 & 0 & 12 & 123 & 164 & 300 & & 600 & Ve \\
\hline חट 10 & $0.3 \%$ & 0 & $4 \%$ & $41 \%$ & $54.7 \%$ & $100 \%$ & .50 & (2) & \\
\hline & 3 & 0 & 8 & 78 & 211 & 300 & & 625 & $\mathrm{Ve}$ \\
\hline 110 & $1 \%$ & 0 & $2.7 \%$ & $26 \%$ & $70.3 \%$ & $100 \%$ & 4.05 & (2) & \\
\hline $\mathrm{HC} 12$ & 2 & 1 & 15 & 111 & 171 & 300 & 4,49 & 672 & Very \\
\hline 11012 & $0.7 \%$ & $0.3 \%$ & $5 \%$ & $37 \%$ & $57 \%$ & $100 \%$ & 4.47 & .012 & int \\
\hline & 2 & 1 & 10 & 109 & 178 & 300 & 472,4 & 646 & $\mathrm{Ve}$ \\
\hline 1. & $0.7 \%$ & $0.3 \%$ & $3.3 \%$ & $36.3 \%$ & $59.3 \%$ & $100 \%$ & 4.05 & .040 & impo \\
\hline HC 14 & 1 & 5 & 8 & 101 & 185 & 300 & 4.55 & .665 & Very \\
\hline
\end{tabular}




\begin{tabular}{|c|c|c|c|c|c|c|c|c|c|}
\hline & $0.3 \%$ & $1.7 \%$ & $2.7 \%$ & $33.6 \%$ & $61.7 \%$ & $100 \%$ & & & important \\
\hline \multirow{2}{*}{$\mathrm{HC} 15$} & 0 & 2 & 13 & 115 & 170 & 300 & \multirow{2}{*}{4.51} & \multirow{2}{*}{.615} & \multirow{2}{*}{$\begin{array}{c}\text { Very } \\
\text { important }\end{array}$} \\
\hline & 0 & $0.7 \%$ & $4.3 \%$ & $38.3 \%$ & $56.7 \%$ & $100 \%$ & & & \\
\hline \multirow{2}{*}{$\mathrm{HC} 16$} & 2 & 0 & 9 & 115 & 174 & 300 & \multirow{2}{*}{4.53} & \multirow{2}{*}{.625} & \multirow{2}{*}{$\begin{array}{c}\text { Very } \\
\text { important }\end{array}$} \\
\hline & $0.7 \%$ & 0 & $3 \%$ & $38.3 \%$ & $58 \%$ & $100 \%$ & & & \\
\hline \multirow{2}{*}{ HC 17} & 0 & 1 & 9 & 112 & 178 & 300 & \multirow{2}{*}{4.56} & \multirow{2}{*}{.573} & \multirow{2}{*}{$\begin{array}{c}\text { Very } \\
\text { important }\end{array}$} \\
\hline & 0 & $0.3 \%$ & $3 \%$ & $37.3 \%$ & $59.3 \%$ & $100 \%$ & & & \\
\hline \multirow{2}{*}{ HC 18} & 1 & 1 & 11 & 116 & 171 & 300 & \multirow{2}{*}{4.52} & \multirow{2}{*}{.620} & \multirow{2}{*}{$\begin{array}{c}\text { Very } \\
\text { important }\end{array}$} \\
\hline & $0.3 \%$ & $0.3 \%$ & $3.7 \%$ & $38.7 \%$ & $57 \%$ & $100 \%$ & & & \\
\hline \multirow{2}{*}{$\mathrm{HC} 19$} & 0 & 2 & 6 & 84 & 208 & 300 & \multirow{2}{*}{4.66} & \multirow{2}{*}{.553} & \multirow{2}{*}{$\begin{array}{c}\text { Very } \\
\text { important }\end{array}$} \\
\hline & 0 & $0.7 \%$ & $2 \%$ & $28 \%$ & $69.3 \%$ & $100 \%$ & & & \\
\hline \multirow{2}{*}{ HC 20} & 0 & 0 & 12 & 106 & 182 & 300 & \multirow{2}{*}{4.57} & \multirow{2}{*}{.572} & \multirow{2}{*}{$\begin{array}{c}\text { Very } \\
\text { important }\end{array}$} \\
\hline & 0 & 0 & $4 \%$ & $35.3 \%$ & $60.7 \%$ & $100 \%$ & & & \\
\hline \multirow{2}{*}{ HC 21} & 0 & 0 & 5 & 114 & 181 & 300 & & 26 & Very \\
\hline & 0 & 0 & $1.7 \%$ & $38 \%$ & $60.3 \%$ & $100 \%$ & 7 & .020 & \\
\hline & 1 & 6 & 28 & 124 & 141 & 300 & 433 & 754 & Very \\
\hline 22 & $0.3 \%$ & $2 \%$ & $9.3 \%$ & $41.3 \%$ & $47 \%$ & $100 \%$ & 4.55 & .134 & $\mathrm{im}$ \\
\hline $\mathrm{HC} 23$ & 0 & 1 & 10 & 123 & 166 & 300 & 451 & 581 & Very \\
\hline 11025 & 0 & $0.3 \%$ & $3.3 \%$ & $41 \%$ & $55.3 \%$ & $100 \%$ & TI & & \\
\hline & 0 & 4 & 6 & 132 & 158 & 300 & & 0 & $\mathrm{Ve}$ \\
\hline III & 0 & $1.3 \%$ & $2 \%$ & $44 \%$ & $52.7 \%$ & $100 \%$ & . & . & \\
\hline & 0 & 1 & 6 & 122 & 171 & 300 & 454 & 556 & Very \\
\hline & 0 & $0.3 \%$ & $2 \%$ & $40.7 \%$ & $57 \%$ & $100 \%$ & 4.04 & טנJ & $\tan t$ \\
\hline $\mathrm{HC} 26$ & 1 & 6 & 7 & 119 & 167 & 300 & 448 & 677 & Very \\
\hline 11020 & $0.3 \%$ & $2 \%$ & $2.3 \%$ & $39.7 \%$ & $55.7 \%$ & $100 \%$ & 4.40 & . & $\tan t$ \\
\hline & 0 & 1 & 6 & 111 & 182 & 300 & 458 & 552 & Very \\
\hline & 0 & $0.3 \%$ & $2 \%$ & $37 \%$ & $60.7 \%$ & $100 \%$ & & & important \\
\hline & 0 & 1 & 9 & 106 & 184 & 300 & & 70 & Very \\
\hline 11020 & 0 & $0.3 \%$ & $3 \%$ & $35.3 \%$ & $61.3 \%$ & $100 \%$ & 4.50 & ט & ant \\
\hline & 0 & 1 & 5 & 108 & 186 & 300 & 0 & 43 & Very \\
\hline & 0 & $0.3 \%$ & $1.7 \%$ & $36 \%$ & $62 \%$ & $100 \%$ & 4.00 & J4 & $\operatorname{rtant}$ \\
\hline HC 30 & 1 & 3 & 9 & 105 & 182 & 300 & 455 & 640 & Very \\
\hline & $0.3 \%$ & $1 \%$ & $3 \%$ & $35 \%$ & $60.7 \%$ & $100 \%$ & $4 . J 3$ & .040 & important \\
\hline & 0 & 1 & 6 & 111 & 182 & 300 & & & \\
\hline 11 & 0 & $0.3 \%$ & $2 \%$ & $37 \%$ & $60.7 \%$ & $100 \%$ & 4.50 & 20. & important \\
\hline $\mathrm{H}$ & 0 & 4 & 21 & 112 & 163 & 300 & 445 & 85 & $\mathrm{Ve}$ \\
\hline 110 & 0 & $1.3 \%$ & $7 \%$ & $37.3 \%$ & $54.3 \%$ & $100 \%$ & $4.4 J$ & (.00 & $\tan t$ \\
\hline $\mathrm{HC} 33$ & 0 & 0 & 11 & 100 & 189 & 300 & 459 & 562 & Very \\
\hline & 0 & 0 & $3.7 \%$ & $33.3 \%$ & $63 \%$ & $100 \%$ & אונ. & & \\
\hline
\end{tabular}




\begin{tabular}{|c|c|c|c|c|c|c|c|c|c|}
\hline \multirow{2}{*}{ HC 34} & 0 & 3 & 4 & 97 & 196 & 300 & \multirow{2}{*}{4.62} & \multirow{2}{*}{.569} & \multirow{2}{*}{$\begin{array}{c}\text { Very } \\
\text { important }\end{array}$} \\
\hline & 0 & $1 \%$ & $1.3 \%$ & $32.3 \%$ & $65.3 \%$ & $100 \%$ & & & \\
\hline \multirow{2}{*}{ HC 35} & 0 & 2 & 9 & 114 & 175 & 300 & \multirow{2}{*}{4.54} & \multirow{2}{*}{.591} & \multirow{2}{*}{$\begin{array}{c}\text { Very } \\
\text { important }\end{array}$} \\
\hline & 0 & $0.7 \%$ & $3 \%$ & $38 \%$ & $58.3 \%$ & $100 \%$ & & & \\
\hline
\end{tabular}

Table (6) shows that the arithmetic means of the responses range from 4.22 to 4.70 and the standard deviations of the responses range from 0.472 to 0.797 . From the table, we can calculate the average mean of all indicators of human capital that equals 4.55 and we can also calculate the average standard deviation which equals 0.598. This means that there is a general trend from respondents to strongly agree on the importance of the indicators that test the first sub-hypothesis related to the importance of using human capital information in measuring performance in Egyptian governmental universities.

\subsubsection{Chi-Square Test}

The following table (7) shows the results of chi-square test of the first sub-hypothesis to determine whether there is a significant difference between observed and expected frequency for all indicators of human capital.

Table ( 7 ) : Chi-Square Test Results

\begin{tabular}{|c|c|c|c|c||}
\hline Item & $\begin{array}{c}\text { Importance } \\
\text { Degree }\end{array}$ & $\begin{array}{c}\text { Degrees of } \\
\text { Freedom }\end{array}$ & $\begin{array}{c}\text { Chi - } \\
\text { Square }\end{array}$ & $\begin{array}{c}\text { Asymp. } \\
\text { Sig. }\end{array}$ \\
\hline \hline HC 1 & $99.3 \%$ & 2 & 225.980 & 0.000 \\
\hline HC 2 & $99.6 \%$ & 2 & 208.620 & 0.000 \\
\hline HC 3 & $98.6 \%$ & 4 & 516.933 & 0.000 \\
\hline HC 4 & $94.3 \%$ & 3 & 237.307 & 0.000 \\
\hline HC 5 & $92.6 \%$ & 3 & 222.080 & 0.000 \\
\hline HC 6 & $97 \%$ & 2 & 179.340 & 0.000 \\
\hline HC 7 & $98.3 \%$ & 3 & 368.560 & 0.000 \\
\hline HC 8 & $98 \%$ & 2 & 188.720 & 0.000 \\
\hline HC 9 & $84.3 \%$ & 4 & 259.633 & 0.000 \\
\hline HC 10 & $95.7 \%$ & 3 & 262.267 & 0.000 \\
\hline HC 11 & $96.3 \%$ & 3 & 375.707 & 0.000 \\
\hline HC 12 & $94 \%$ & 4 & 396.533 & 0.000 \\
\hline HC 13 & $95.6 \%$ & 4 & 427.833 & 0.000 \\
\hline HC 14 & $95.3 \%$ & 4 & 441.933 & 0.000 \\
\hline HC 15 & $95 \%$ & 3 & 263.973 & 0.000 \\
\hline \hline
\end{tabular}




\begin{tabular}{||c|c|c|c|c||}
\hline HC 16 & $96.3 \%$ & 3 & 281.147 & 0.000 \\
\hline HC 17 & $96.6 \%$ & 3 & 290.800 & 0.000 \\
\hline HC 18 & $95.7 \%$ & 4 & 413.667 & 0.000 \\
\hline HC 19 & $97.3 \%$ & 3 & 371.467 & 0.000 \\
\hline HC 20 & $96 \%$ & 2 & 145.040 & 0.000 \\
\hline HC 21 & $98.3 \%$ & 2 & 157.820 & 0.000 \\
\hline HC 22 & $88.3 \%$ & 4 & 301.300 & 0.000 \\
\hline HC 23 & $96.3 \%$ & 3 & 270.480 & 0.000 \\
\hline HC 24 & $96.7 \%$ & 3 & 265.867 & 0.000 \\
\hline HC 25 & $97.7 \%$ & 3 & 288.827 & 0.000 \\
\hline HC 26 & $95.4 \%$ & 4 & 402.267 & 0.000 \\
\hline HC 27 & $97.7 \%$ & 3 & 306.427 & 0.000 \\
\hline HC 28 & $96.6 \%$ & 3 & 302.320 & 0.000 \\
\hline HC 29 & $98 \%$ & 3 & 317.147 & 0.000 \\
\hline HC 30 & $95.7 \%$ & 4 & 437.333 & 0.000 \\
\hline HC 31 & $97.7 \%$ & 3 & 306.427 & 0.000 \\
\hline HC 32 & $91.6 \%$ & 3 & 227.600 & 0.000 \\
\hline HC 33 & $96.3 \%$ & 2 & 158.420 & 0.000 \\
\hline HC 34 & $97.6 \%$ & 3 & 338.000 & 0.000 \\
\hline HC 35 & $96.3 \%$ & 3 & 282.747 & 0.000 \\
\hline
\end{tabular}

The previous table (7) shows that the Sig. of all indicators of human capital is less than $\alpha=0.05$ which means that there is a significant difference between observed frequencies and expected ones; this indicates the importance of using human capital information in measuring performance in Egyptian governmental universities.

\subsubsection{Friedman Test}

Table (8) below shows the results of Friedman test which indicate whether there is a significant difference between the responses of the respondents about the importance of human capital indicators affecting performance measurement in Egyptian governmental universities.

Table ( 8 ) : Friedman Test Results

\begin{tabular}{|c|c|c|c|c|}
\hline Item & $\begin{array}{c}\text { Mean } \\
\text { Rank }\end{array}$ & $\begin{array}{c}\text { Importance } \\
\text { Rank }\end{array}$ & $\begin{array}{c}\text { Chi - } \\
\text { Square }\end{array}$ & $\begin{array}{c}\text { Asymp. } \\
\text { Sig. }\end{array}$ \\
\hline \hline HC 1 & 20.19 & $\mathbf{1}$ & 407.895 & 0.000 \\
\hline
\end{tabular}




\begin{tabular}{|c|c|c|}
\hline HC 2 & 19.82 & 3 \\
\hline HC 3 & 19.47 & 6 \\
\hline $\mathrm{HC} 4$ & 16.07 & 32 \\
\hline HC 5 & 15.73 & 33 \\
\hline HC 6 & 19.21 & 8 \\
\hline $\mathrm{HC} 7$ & 19.65 & 5 \\
\hline $\mathrm{HC} 8$ & 19.35 & 7 \\
\hline $\mathrm{HC} 9$ & 13.80 & 35 \\
\hline $\mathrm{HC} 10$ & 17.12 & 29 \\
\hline $\mathrm{HC} 11$ & 19.84 & 2 \\
\hline $\mathrm{HC} 12$ & 17.39 & 26 \\
\hline $\mathrm{HC} 13$ & 17.93 & 20 \\
\hline $\mathrm{HC} 14$ & 18.27 & 16 \\
\hline $\mathrm{HC} 15$ & 17.41 & 25 \\
\hline $\mathrm{HC} 16$ & 17.79 & 22 \\
\hline $\mathrm{HC} 17$ & 18.04 & 19 \\
\hline $\mathrm{HC} 18$ & 17.50 & 24 \\
\hline $\mathrm{HC} 19$ & 19.78 & 4 \\
\hline HC 20 & 18.23 & 17 \\
\hline HC 21 & 18.43 & 14 \\
\hline $\mathrm{HC} 22$ & 15.00 & 34 \\
\hline HC 23 & 17.37 & 27 \\
\hline HC 24 & 16.93 & 30 \\
\hline HC 25 & 17.77 & 23 \\
\hline HC 26 & 17.25 & 28 \\
\hline HC 27 & 18.46 & 12 \\
\hline HC 28 & 18.39 & 15 \\
\hline HC 29 & 18.65 & 11 \\
\hline HC 30 & 18.16 & 18 \\
\hline HC 31 & 18.45 & 13 \\
\hline HC 32 & 16.81 & 31 \\
\hline HC 33 & 18.70 & 10 \\
\hline HC 34 & 19.18 & 9 \\
\hline HC 35 & 17.87 & 21 \\
\hline
\end{tabular}


The results of Friedman test shown in table (8) indicate that the Sig. of the test equals zero which is less than $\alpha=0.05$, this means that there is a significant difference between responses of the respondents about the importance of human capital indicators affecting performance measurement process in universities. The results also show that the most important human capital indicator is announcing the appointment rules of faculty staff and their assistants (indicator no.1), followed by ratio of researches published internationally to the total number of faculty staff and their assistants (indicator no.11), and the least important indicator of human capital is ratio of issued books to the total number of faculty staff (indicator no.9).

From the previous statistical analysis of the first subhypothesis, concerning with the importance of human capital indicators in measuring performance, we can reject the null hypothesis and accept the alternative one that confirms the importance of using human capital information in measuring performance in Egyptian governmental universities.

\subsubsection{Testing the Second Sub-Hypothesis}

The second sub-hypothesis is formulated in the null and alternative forms as follow:

$\mathbf{H}_{\mathbf{0}}$ : Using structural capital information is not important in measuring performance in governmental universities in Egypt.

$\mathbf{H}_{1}$ : Using structural capital information has a significant importance in measuring performance in governmental universities in Egypt.

\subsubsection{Analysis of Ratios}

Table (9) shows the results of frequencies, percentages, means, and standard deviations for phrases from 1 to 20 in the questionnaire.

Table (9) : Frequencies, Percentages, Means, and Standard Deviations

\begin{tabular}{|c|c|c|c|c|c|c|c|c|c|}
\hline Item & 1 & 2 & 3 & 4 & 5 & Total & Mean & $\begin{array}{c}\text { Std. } \\
\text { Deviat } \\
\text { ion }\end{array}$ & $\begin{array}{c}\text { General } \\
\text { Trend }\end{array}$ \\
\hline \multirow{2}{*}{$\mathrm{SC} 1$} & 0 & 1 & 7 & 102 & 190 & 300 & \multirow{2}{*}{4.60} & \multirow{2}{*}{.554} & \multirow{2}{*}{$\begin{array}{c}\text { Very } \\
\text { important }\end{array}$} \\
\hline & 0 & $0.3 \%$ & $2.3 \%$ & $34 \%$ & $63.3 \%$ & $100 \%$ & & & \\
\hline \multirow{2}{*}{ SC 2} & 0 & 0 & 5 & 109 & 186 & 300 & \multirow{2}{*}{4.60} & \multirow{2}{*}{.523} & \multirow{2}{*}{$\begin{array}{c}\text { Very } \\
\text { important }\end{array}$} \\
\hline & 0 & 0 & $1.7 \%$ & $36.3 \%$ & $62 \%$ & $100 \%$ & & & \\
\hline \multirow{2}{*}{$\mathrm{SC} 3$} & 0 & 1 & 7 & 124 & 168 & 300 & \multirow{2}{*}{4.53} & \multirow{2}{*}{.563} & \multirow{2}{*}{$\begin{array}{c}\text { Very } \\
\text { important }\end{array}$} \\
\hline & 0 & $0.3 \%$ & $2.3 \%$ & $41.3 \%$ & $56 \%$ & $100 \%$ & & & \\
\hline $\mathrm{SC} 4$ & 0 & 1 & 6 & 129 & 164 & 300 & 4.52 & .557 & Very \\
\hline
\end{tabular}




\begin{tabular}{|c|c|c|c|c|c|c|c|c|c|}
\hline & 0 & 0.3 & $2 \%$ & $43 \%$ & $54.7 \%$ & $100 \%$ & & & important \\
\hline \multirow{2}{*}{ SC 5} & 0 & 2 & 6 & 105 & 187 & 300 & \multirow{2}{*}{4.59} & \multirow{2}{*}{.568} & \multirow{2}{*}{$\begin{array}{c}\text { Very } \\
\text { important }\end{array}$} \\
\hline & 0 & $0.7 \%$ & $2 \%$ & $35 \%$ & $62.3 \%$ & $100 \%$ & & & \\
\hline \multirow{2}{*}{ SC 6} & 0 & 0 & 9 & 113 & 178 & 300 & \multirow{2}{*}{4.56} & \multirow{2}{*}{.554} & \multirow{2}{*}{$\begin{array}{c}\text { Very } \\
\text { important }\end{array}$} \\
\hline & 0 & 0 & $3 \%$ & $37.7 \%$ & $59.3 \%$ & $100 \%$ & & & \\
\hline \multirow{2}{*}{ SC 7} & 0 & 2 & 14 & 123 & 161 & 300 & \multirow{2}{*}{4.48} & \multirow{2}{*}{.620} & \multirow{2}{*}{$\begin{array}{c}\text { Very } \\
\text { important }\end{array}$} \\
\hline & 0 & $0.7 \%$ & $4.7 \%$ & $41 \%$ & $53.6 \%$ & $100 \%$ & & & \\
\hline \multirow{2}{*}{ SC 8} & 0 & 4 & 5 & 107 & 184 & 300 & \multirow{2}{*}{4.57} & \multirow{2}{*}{.600} & \multirow{2}{*}{$\begin{array}{c}\text { Very } \\
\text { important }\end{array}$} \\
\hline & 0 & $1.3 \%$ & $1.7 \%$ & $35.7 \%$ & $61.3 \%$ & $100 \%$ & & & \\
\hline \multirow{2}{*}{ SC 9} & 0 & 2 & 6 & 108 & 184 & 300 & \multirow{2}{*}{4.58} & \multirow{2}{*}{.570} & \multirow{2}{*}{$\begin{array}{c}\text { Very } \\
\text { important }\end{array}$} \\
\hline & 0 & $0.7 \%$ & $2 \%$ & $36 \%$ & $61.3 \%$ & $100 \%$ & & & \\
\hline \multirow{2}{*}{$\mathrm{SC} 10$} & 1 & 0 & 5 & 111 & 183 & 300 & \multirow{2}{*}{4.58} & \multirow{2}{*}{.563} & \multirow{2}{*}{$\begin{array}{c}\text { Very } \\
\text { important }\end{array}$} \\
\hline & $0.3 \%$ & 0 & $1.7 \%$ & $37 \%$ & $61 \%$ & $100 \%$ & & & \\
\hline \multirow{2}{*}{ SC 11} & 0 & 0 & 2 & 107 & 191 & 300 & \multirow{2}{*}{4.63} & \multirow{2}{*}{.497} & \multirow{2}{*}{$\begin{array}{c}\text { Very } \\
\text { important }\end{array}$} \\
\hline & 0 & 0 & $0.7 \%$ & $35.7 \%$ & $63.6 \%$ & $100 \%$ & & & \\
\hline SC 12 & 1 & 0 & 5 & 111 & 183 & 300 & 4.58 & 563 & Very \\
\hline $\mathrm{SC} 12$ & $0.3 \%$ & 0 & $1.7 \%$ & $37 \%$ & $61 \%$ & $100 \%$ & 4.58 & .563 & important \\
\hline $\mathrm{SC} 13$ & 0 & 0 & 3 & 103 & 194 & 300 & 464 & 502 & Very \\
\hline$S<13$ & 0 & 0 & $1 \%$ & $34.3 \%$ & $64.7 \%$ & $100 \%$ & 4.04 & .502 & important \\
\hline $\mathrm{SC} 14$ & 0 & 4 & 3 & 105 & 188 & 300 & 450 & 586 & Very \\
\hline $\mathrm{SC} 14$ & 0 & $1.3 \%$ & $1 \%$ & $35 \%$ & $62.7 \%$ & $100 \%$ & 4.59 & .580 & important \\
\hline & 0 & 3 & 8 & 108 & 181 & 300 & 456 & & Very \\
\hline $\mathrm{sc} 15$ & 0 & $1 \%$ & $2.7 \%$ & $36 \%$ & $60.3 \%$ & $100 \%$ & 4.56 & .601 & important \\
\hline $\mathrm{SC} 16$ & 1 & 1 & 8 & 87 & 203 & 300 & 463 & & \\
\hline $\mathrm{SC} 16$ & $0.3 \%$ & $0.3 \%$ & $2.7 \%$ & $29 \%$ & $67.7 \%$ & $100 \%$ & 4.63 & .589 & important \\
\hline $\mathrm{SC} 17$ & 0 & 0 & 4 & 96 & 200 & 300 & 465 & 504 & Very \\
\hline $\mathrm{sc} 11$ & 0 & 0 & $1.3 \%$ & $32 \%$ & $66.7 \%$ & $100 \%$ & 4.05 & .504 & important \\
\hline $\mathrm{SC} 18$ & 0 & 1 & 6 & 102 & 191 & 300 & 461 & 547 & Very \\
\hline & 0 & $0.3 \%$ & $2 \%$ & $34 \%$ & $63.7 \%$ & $100 \%$ & & & important \\
\hline & 0 & 1 & 12 & 118 & 169 & 300 & 452 & 592 & Very \\
\hline SC 19 & 0 & $0.3 \%$ & $4 \%$ & $39.3 \%$ & $56.4 \%$ & $100 \%$ & 4.52 & .092 & important \\
\hline & 0 & 0 & 3 & 99 & 198 & 300 & 465 & 498 & Very \\
\hline & 0 & 0 & $1 \%$ & $33 \%$ & $66 \%$ & $100 \%$ & 4.05 & .498 & important \\
\hline
\end{tabular}

Table (9) shows that the arithmetic means of the responses range from 4.48 to 4.65 and the standard deviations of the responses range from 0.497 to 0.620 . From the table, we can calculate the average mean of all indicators of structural capital that equals 4.58 and the average standard deviation which equals 0.558 . This means that there is a general trend from respondents to strongly agree on the 
importance of the indicators that test the second sub-hypothesis related to the importance of using structural capital information in measuring performance in Egyptian governmental universities.

\subsubsection{Chi-Square Test}

The following table (10) shows the results of chi-square test of the second sub-hypothesis to determine whether there is a significant difference between observed and expected frequency for all indicators of structural capital.

Table ( 10 ) : Chi-Square Test Results

\begin{tabular}{|c|c|c|c|c||}
\hline Item & $\begin{array}{c}\text { Importance } \\
\text { Degree }\end{array}$ & $\begin{array}{c}\text { Degrees of } \\
\text { Freedom }\end{array}$ & $\begin{array}{c}\text { Chi - } \\
\text { Square }\end{array}$ & $\begin{array}{c}\text { Asymp. } \\
\text { Sig. }\end{array}$ \\
\hline \hline SC 1 & $97.3 \%$ & 3 & 320.720 & 0.000 \\
\hline SC 2 & $98.3 \%$ & 2 & 165.020 & 0.000 \\
\hline SC 3 & $97.3 \%$ & 3 & 282.000 & 0.000 \\
\hline SC 4 & $97.7 \%$ & 3 & 280.987 & 0.000 \\
\hline SC 5 & $97.3 \%$ & 3 & 313.787 & 0.000 \\
\hline SC 6 & $97 \%$ & 2 & 145.340 & 0.000 \\
\hline SC 7 & $94.6 \%$ & 3 & 250.000 & 0.000 \\
\hline SC 8 & $97 \%$ & 3 & 304.613 & 0.000 \\
\hline SC 9 & $97.3 \%$ & 3 & 307.467 & 0.000 \\
\hline SC 10 & $98 \%$ & 3 & 311.147 & 0.000 \\
\hline SC 11 & $99.3 \%$ & 2 & 179.340 & 0.000 \\
\hline SC 12 & $98 \%$ & 3 & 311.147 & 0.000 \\
\hline SC 13 & $99 \%$ & 2 & 182.540 & 0.000 \\
\hline SC 14 & $97.7 \%$ & 3 & 318.587 & 0.000 \\
\hline SC 15 & $96.3 \%$ & 3 & 293.307 & 0.000 \\
\hline SC 16 & $96.7 \%$ & 4 & 514.067 & 0.000 \\
\hline SC 17 & $98.7 \%$ & 2 & 192.320 & 0.000 \\
\hline SC 18 & $97.7 \%$ & 3 & 325.627 & 0.000 \\
\hline SC 19 & $95.7 \%$ & 3 & 268.400 & 0.000 \\
\hline SC 20 & $99 \%$ & 2 & 190.140 & 0.000 \\
\hline
\end{tabular}

The previous table (10) shows that Sig. of all indicators of structural capital is less than $\alpha=0.05$ which means that there is a significant difference between observed frequencies and expected ones; this indicates the importance of using structural capital 
information in measuring performance in Egyptian governmental universities.

\subsubsection{Friedman Test}

Table (11) below shows the results of Friedman test which indicate whether there is a significant difference between the responses of the respondents about the importance of structural capital indicators affecting performance measurement in Egyptian governmental universities.

Table ( 11 ) : Friedman Test Results

\begin{tabular}{|c|c|c|c|c|}
\hline Item & $\begin{array}{l}\text { Mean } \\
\text { Rank }\end{array}$ & $\begin{array}{c}\text { Importance } \\
\text { Rank }\end{array}$ & $\begin{array}{c}\text { Chi - } \\
\text { Square }\end{array}$ & $\begin{array}{c}\text { Asymp. } \\
\text { Sig. }\end{array}$ \\
\hline $\mathrm{SC} 1$ & 10.67 & 7 & \multirow{17}{*}{73.406} & \multirow{17}{*}{0.000} \\
\hline $\mathrm{SC} 2$ & 10.59 & 9 & & \\
\hline SC 3 & 9.96 & 17 & & \\
\hline $\mathrm{SC} 4$ & 9.85 & 19 & & \\
\hline SC 5 & 10.59 & 10 & & \\
\hline SC 6 & 10.27 & 16 & & \\
\hline SC 7 & 9.51 & 20 & & \\
\hline SC 8 & 10.47 & 14 & & \\
\hline SC 9 & 10.47 & 13 & & \\
\hline SC 10 & 10.51 & 11 & & \\
\hline SC 11 & 10.86 & 5 & & \\
\hline SC 12 & 10.50 & 12 & & \\
\hline SC 13 & 10.91 & 4 & & \\
\hline SC 14 & 10.65 & 8 & & \\
\hline SC 15 & 10.35 & 15 & & \\
\hline SC 16 & 11.06 & 2 & & \\
\hline SC 17 & 11.12 & 1 & & \\
\hline SC 18 & 10.71 & 6 & & \\
\hline SC 19 & 9.93 & 18 & & \\
\hline SC 20 & 11.03 & 3 & & \\
\hline
\end{tabular}

The results of Friedman test shown in table (11) indicate that the Sig. of the test equals zero which is less than $\alpha=0.05$, this means that that there is a significant difference between responses of the respondents about structural capital indicators affecting performance measurement process in universities. The results also show that the 
most important structural capital indicator is ratio of patents registered in the name of the university to the total patents in the rest of the universities (indicator no.17), followed by clarifying the budget value allocated for spending on scientific research and its percentage to the total budget allocated to the university and the means used for its development (indicator no. 16), and the least important indicator of structural capital is suitability of the number of computers existed in computer labs to the total number of students and researchers (indicator no. 7).

From the previous statistical analysis of the second subhypothesis, concerning with the importance of structural capital indicators in measuring performance, we can reject the null hypothesis and accept the alternative one that confirms the importance of using structural capital information in measuring performance in Egyptian governmental universities.

\subsubsection{Testing the Third Sub-Hypothesis}

The third sub-hypothesis is formulated in the null and alternative forms as follow:

$\mathbf{H}_{\mathbf{0}}$ : Using relational capital information is not important in measuring performance in governmental universities in Egypt.

$\mathbf{H}_{1}$ : Using relational capital information has a significant importance in measuring performance in governmental universities in Egypt.

\subsubsection{Analysis of Ratios}

Table (12) shows the results of frequencies, percentages, means, and standard deviations for phrases from 1 to 10 in the questionnaire.

Table ( 12 ) : Frequencies, Percentages, Means, and Standard Deviations

\begin{tabular}{|c|c|c|c|c|c|c|c|c|c|}
\hline Item & 1 & 2 & 3 & 4 & 5 & Total & Mean & $\begin{array}{c}\text { Std. } \\
\text { Deviati } \\
\text { on }\end{array}$ & $\begin{array}{c}\text { General } \\
\text { Trend }\end{array}$ \\
\hline \multirow{2}{*}{$\mathrm{RC} 1$} & 0 & 0 & 11 & 91 & 198 & 300 & \multirow{2}{*}{4.62} & \multirow{2}{*}{.556} & \multirow{2}{*}{$\begin{array}{c}\text { Very } \\
\text { important }\end{array}$} \\
\hline & 0 & 0 & $3.7 \%$ & $30.3 \%$ & $66 \%$ & $100 \%$ & & & \\
\hline \multirow{2}{*}{$\mathrm{RC} 2$} & 1 & 2 & 6 & 101 & 190 & 300 & \multirow{2}{*}{4.59} & \multirow{2}{*}{.603} & \multirow{2}{*}{$\begin{array}{c}\text { Very } \\
\text { important }\end{array}$} \\
\hline & $0.3 \%$ & $0.7 \%$ & $2 \%$ & $33.7 \%$ & $63.3 \%$ & $100 \%$ & & & \\
\hline \multirow{2}{*}{ RC 3} & 0 & 2 & 8 & 108 & 182 & 300 & \multirow{2}{*}{4.57} & \multirow{2}{*}{.583} & \multirow{2}{*}{$\begin{array}{c}\text { Very } \\
\text { important }\end{array}$} \\
\hline & 0 & $0.7 \%$ & $2.7 \%$ & $36 \%$ & $60.6 \%$ & $100 \%$ & & & \\
\hline
\end{tabular}

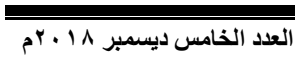




\begin{tabular}{|c|c|c|c|c|c|c|c|c|c|}
\hline \multirow{2}{*}{$\mathrm{RC} 4$} & 0 & 1 & 8 & 106 & 185 & 300 & \multirow{2}{*}{4.58} & \multirow{2}{*}{.563} & \multirow{2}{*}{$\begin{array}{c}\text { Very } \\
\text { important }\end{array}$} \\
\hline & 0 & $0.3 \%$ & $2.7 \%$ & $35.3 \%$ & $61.7 \%$ & $100 \%$ & & & \\
\hline \multirow{2}{*}{ RC 5} & 0 & 1 & 10 & 110 & 179 & 300 & \multirow{2}{*}{4.56} & \multirow{2}{*}{.578} & \multirow{2}{*}{$\begin{array}{c}\text { Very } \\
\text { important }\end{array}$} \\
\hline & 0 & $0.3 \%$ & $3.3 \%$ & $36.7 \%$ & $59.7 \%$ & $100 \%$ & & & \\
\hline \multirow{2}{*}{$\mathrm{RC} 6$} & 1 & 1 & 6 & 93 & 199 & 300 & \multirow{2}{*}{4.63} & \multirow{2}{*}{.579} & \multirow{2}{*}{$\begin{array}{c}\text { Very } \\
\text { important }\end{array}$} \\
\hline & $0.3 \%$ & $0.3 \%$ & $2 \%$ & $31 \%$ & $66.4 \%$ & $100 \%$ & & & \\
\hline \multirow{2}{*}{$\mathrm{RC} 7$} & 0 & 0 & 3 & 104 & 193 & 300 & \multirow{2}{*}{4.63} & \multirow{2}{*}{.503} & \multirow{2}{*}{$\begin{array}{c}\text { Very } \\
\text { important }\end{array}$} \\
\hline & 0 & 0 & $1 \%$ & $34.7 \%$ & $64.3 \%$ & $100 \%$ & & & \\
\hline \multirow{2}{*}{$\mathrm{RC} 8$} & 0 & 0 & 9 & 89 & 202 & 300 & \multirow{2}{*}{4.64} & \multirow{2}{*}{.539} & \multirow{2}{*}{$\begin{array}{c}\text { Very } \\
\text { important }\end{array}$} \\
\hline & 0 & 0 & $3 \%$ & $29.7 \%$ & $67.3 \%$ & $100 \%$ & & & \\
\hline \multirow{2}{*}{ RC 9} & 0 & 0 & 3 & 100 & 197 & 300 & \multirow{2}{*}{4.65} & \multirow{2}{*}{.499} & \multirow{2}{*}{$\begin{array}{c}\text { Very } \\
\text { important }\end{array}$} \\
\hline & 0 & 0 & $1 \%$ & $33.3 \%$ & $65.7 \%$ & $100 \%$ & & & \\
\hline \multirow{2}{*}{$\mathrm{RC} 10$} & 0 & 1 & 6 & 95 & 198 & 300 & \multirow{2}{*}{4.63} & \multirow{2}{*}{.541} & \multirow{2}{*}{$\begin{array}{c}\text { Very } \\
\text { important }\end{array}$} \\
\hline & 0 & $0.3 \%$ & $2 \%$ & $31.7 \%$ & $66 \%$ & $100 \%$ & & & \\
\hline
\end{tabular}

Table (12) shows that the arithmetic means of the responses range from 4.57 to 4.65 , and the standard deviations range from 0.499 to 0.603 , the average mean of all indicators of relational capital is 4.61 and the average standard deviation 0.554 . This means that there is a general trend from respondents to strongly agree on the importance of the indicators that test the third sub-hypothesis related to the importance of using relational capital information in measuring performance in Egyptian governmental universities.

\subsubsection{Chi-Square Test}

The following table (13) shows the results of chi-square test of the third sub-hypothesis to determine whether there is a significant difference between observed and expected frequency for all indicators of relational capital.

Table ( 13 ) : Chi-Square Test Results

\begin{tabular}{|c|c|c|c|c|}
\hline Item & $\begin{array}{c}\text { Importance } \\
\text { Degree }\end{array}$ & $\begin{array}{c}\text { Degrees of } \\
\text { Freedom }\end{array}$ & $\begin{array}{c}\text { Chi - } \\
\text { Square }\end{array}$ & $\begin{array}{c}\text { Asymp. } \\
\text { Sig. }\end{array}$ \\
\hline \hline RC 1 & $96.3 \%$ & 2 & 176.060 & 0.000 \\
\hline RC 2 & $97 \%$ & 4 & 472.367 & 0.000 \\
\hline RC 3 & $96.6 \%$ & 3 & 298.080 & 0.000 \\
\hline RC 4 & $97 \%$ & 3 & 307.013 & 0.000 \\
\hline RC 5 & $96.4 \%$ & 3 & 289.893 & 0.000 \\
\hline RC 6 & $97.4 \%$ & 4 & 504.800 & 0.000 \\
\hline RC 7 & $99 \%$ & 2 & 180.740 & 0.000 \\
\hline RC 8 & $97 \%$ & 2 & 188.060 & 0.000 \\
\hline \hline
\end{tabular}




\begin{tabular}{|c|c|c|c|c|}
\hline RC 9 & $99 \%$ & 2 & 188.180 & 0.000 \\
\hline RC 10 & $97.7 \%$ & 3 & 343.547 & 0.000 \\
\hline
\end{tabular}

The previous table (13) shows that Sig. of all indicators of relational capital is less than $\alpha=0.05$ which means that there is a significant difference between observed frequencies and expected ones; this indicates the importance of using relational capital information in measuring performance in Egyptian governmental universities.

\subsubsection{Friedman Test}

Table (14) below shows the results of Friedman test which indicate whether there is a significant difference between the responses of the respondents about the importance of relational capital indicators affecting performance measurement in Egyptian governmental universities.

Table ( 14 ) : Friedman Test Results

\begin{tabular}{|c|c|c|c|c|}
\hline Item & $\begin{array}{l}\text { Mean } \\
\text { Rank }\end{array}$ & $\begin{array}{c}\text { Importance } \\
\text { Rank }\end{array}$ & $\begin{array}{c}\text { Chi - } \\
\text { Square }\end{array}$ & $\begin{array}{l}\text { Asymp. } \\
\text { Sig. }\end{array}$ \\
\hline 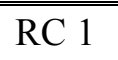 & 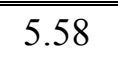 & 5 & \multirow{10}{*}{20.087} & \multirow{10}{*}{0.017} \\
\hline RC 2 & 5.46 & 7 & & \\
\hline RC 3 & 5.31 & 9 & & \\
\hline $\mathrm{RC} 4$ & 5.36 & 8 & & \\
\hline RC 5 & 5.22 & 10 & & \\
\hline RC 6 & 5.59 & 4 & & \\
\hline RC 7 & 5.56 & 6 & & \\
\hline RC 8 & 5.67 & 1 & & \\
\hline RC 9 & 5.64 & 2 & & \\
\hline $\mathrm{RC} 10$ & 5.63 & 3 & & \\
\hline
\end{tabular}

The results of Friedman test shown in table (14) indicate that the Sig. of the test equals 0.017 which is less than $\alpha=0.05$; this means that there is a significant difference between the responses of the respondents about relational capital indicators affecting performance measurement. The results also show that the most important relational capital indicator affecting performance measurement is the number of university research partnerships applied with industrial bodies (indicator no.8), followed by measuring the opinions of students and benefiting from the results in taking corrective action and increasing student satisfaction (indicator no.9), and the least important indicator 
of relational capital is the ratio of trained students in courses provided by different Egyptian bodies to the total number of students (indicator no.5).

From the previous statistical analysis of the third subhypothesis, concerning with the importance of relational capital indicators in measuring performance, we can reject the null hypothesis and accept the alternative one that confirms the importance of using relational capital information in measuring performance in Egyptian governmental universities.

\subsubsection{Order of IC Components According to their Importance}

After testing the hypotheses and concluding that using the three components of intellectual capital (human capital, structural capital and relational capital) has a significant importance in measuring performance in universities, it should be determined which of the three components is the most important one in measuring performance in universities. Therefore, Friedman test was conducted on the three variables to order them according to their importance and the following table (15) shows the results of Friedman test:

Table ( 15 ) : Friedman Test Results

\begin{tabular}{|c|c|c|c|c|}
\hline Item & $\begin{array}{l}\text { Mean } \\
\text { Rank } \\
\end{array}$ & $\begin{array}{c}\text { Importance } \\
\text { Rank }\end{array}$ & \begin{tabular}{|c|} 
Chi - \\
Square
\end{tabular} & $\begin{array}{c}\text { Asymp. } \\
\text { Sig. }\end{array}$ \\
\hline $\begin{array}{l}\text { Importance of using human } \\
\text { capital information in } \\
\text { measuring performance in } \\
\text { Egyptian governmental } \\
\text { universities }\end{array}$ & 1.83 & 3 & \multirow{3}{*}{18.469} & \multirow{3}{*}{0.000} \\
\hline $\begin{array}{l}\text { Importance of using } \\
\text { structural capital information } \\
\text { in measuring performance in } \\
\text { Egyptian governmental } \\
\text { universities }\end{array}$ & 2.05 & 2 & & \\
\hline $\begin{array}{l}\text { Importance of using } \\
\text { relational capital information } \\
\text { in measuring performance in } \\
\text { Egyptian governmental } \\
\text { universities }\end{array}$ & 2.12 & 1 & & \\
\hline
\end{tabular}


From table (15), we can conclude that using relational capital information is the most important variable in measuring performance in governmental universities, followed by using structural capital information and using human capital information comes at the end.

\subsubsection{The Descriptive Analysis of the Three Questions about IC Disclosure for Universities}

The researcher asked three questions in the questionnaire about intellectual capital disclosure for universities to present the views of respondents about this issue; this is because intellectual capital disclosure for universities became mandatory in some countries. Table (16) below shows the frequencies and percentages of the three questions related to intellectual capital disclosure for Egyptian governmental universities:

Table ( 16 ) : Frequencies, Percentages, and General Trend

\begin{tabular}{|c|c|c|c|c|}
\hline \multirow{2}{*}{ Item } & Yes & No & Total & $\begin{array}{c}\text { General } \\
\text { Trend }\end{array}$ \\
\hline \hline \multirow{2}{*}{ D 1 } & 293 & 7 & 300 & Yes \\
\cline { 2 - 4 } & $97.7 \%$ & $2.3 \%$ & $100 \%$ & \\
\hline \multirow{2}{*}{ D 2 } & 288 & 12 & 300 & \multirow{2}{*}{ Yes } \\
\cline { 2 - 4 } & $96 \%$ & $4 \%$ & $100 \%$ & \\
\hline \multirow{2}{*}{ D 3 } & 297 & 3 & 300 & \multirow{2}{*}{ Yes } \\
\cline { 2 - 4 } & $99 \%$ & $1 \%$ & $100 \%$ & \multirow{2}{*}{} \\
\hline
\end{tabular}

Table (16) shows that $97.7 \%$ of the sample supported the importance of obligating Egyptian governmental universities to disclose their intellectual capital information and $96 \%$ of the sample believed that intellectual capital discourse of universities will affect the performance measurement process and $99 \%$ of the sample thought that this disclosure will contribute in improving the performance of Egyptian governmental universities.

\section{Conclusion, Results, and Recommendations}

\subsection{Conclusion}

The main purpose of this research is to investigate the importance of using intellectual capital information in

مجلة الاراسات التجارية المعاصرة


measuring performance in Egyptian governmental universities. In order to achieve this purpose, the research was divided into two parts: the theoretical framework that introduced an overview about the aspects of the topic and also displayed the previous efforts in this area; and the field study that tested the research hypotheses through designing a structured questionnaire and distributing it on a sample consisting of a group of faculty staffs, postgraduate students, and undergraduate students from Egyptian governmental universities.

\subsection{Results}

The results of the theoretical and the field study can be summarized as follow:

1. Performance measurement in universities is an important topic that researchers began to exert more attention to it, because higher education is the backbone of any nation, if universities measure their performance accurately and efficiently, they can improve their performance "what we can measure is what we can get". Therefore, countries always seek to improve performance of universities to achieve development of nations.

2. There are several problems facing universities when measuring performance, the most important ones are lack of sufficient financial resources, lack of motivation and low morale, goal diversity and ambiguity, strategy implementation, resistance to performance measurement.

3. There is a sharp decline in the presence of Egyptian governmental universities within the global rankings of universities; this is due to lack of attention to performance measurement, which in turn led to lower performance at universities.

4. Literatures confirmed that intellectual capital has a significant impact on performance of universities, since intellectual capital is the main product of universities and universities are considered as a factory of intellectual capital.

5. Using intellectual capital information has a significant importance in measuring performance in Egyptian governmental universities that could lead universities to enhance their performance. 
6. The three components of intellectual capital (human capital, structural capital and relational capital) have a significant importance in measuring performance in Egyptian governmental universities, but the most important one is relational capital followed by structural capital and human capital. This result is consistent with the results of Shojaie and Barani (2013).

7. The most important human capital indicators affecting performance measurement in Egyptian governmental universities are "announcing the appointment rules of faculty staff and their assistants" ( $\mathrm{HC} 1$ ), followed by "ratio of researches published internationally to the total number of faculty staff and their assistants" (HC 11).

8. The most important structural capital indicators affecting performance measurement in Egyptian governmental universities are "ratio of patents registered in the name of the university to the total patents in the rest of the universities" (SC 17), followed by "clarifying the budget value allocated for spending on scientific research and its percentage to the total budget allocated to the university and the means used for its development" (SC 16).

9. The most important relational capital indicators affecting performance measurement in Egyptian governmental universities are "the number of university research partnerships applied with industrial bodies" (RC 8), followed by "measuring the opinions of students and benefiting from the results in taking corrective action and increasing student satisfaction" (RC 9).

10. Intellectual capital indicators (human capital indicators, structural capital indicators, and relational capital indicators) are considered as a good tool for measuring performance in universities.

11. Finally, intellectual capital disclosure could be of a great importance for universities because it will create the spirit of competition between Egyptian governmental universities and this will contribute to enhancing their performance.

\subsection{Recommendations}

1. The necessity for Egyptian governmental universities to use intellectual capital indicators in measuring performance, 
because of their considerable role in facilitating performance measurement process.

2. The necessity for Egyptian governmental universities to disclose their intellectual capital, because foreign experiences proved the important role of intellectual capital disclosure in enhancing performance in universities.

3. Universities should exert more attention to performance measurement process to improve their performance and to enhance their situations in the global rankings.

4. The necessity for conducting further research to ensure that intellectual capital disclosure improves the performance of universities.

\section{References}

1. Ahmadi, F., Parivizi, B., Meyhami, B. \& Ziaee, M. (2012), "Intellectual Capital Accounting and its Role in Creating Competitive Advantage at the Universities". Interdisciplinary journal of contemporary research in business, Vol. 4, No. 1, p. 894-912.

2. Alboushra, M.A., Shahbudin, A.S. \& Abdalla, Y.A. (2015), "Understanding Challenges of Performance Measurement in a Public University: Evidence from Sudan". Asian Social Science, Vol. 11, No. 15, p. 10-21.

3. Arafat, I.Z. (2011), "Proposed Framework for Accounting Disclosure of Intellectual Capital in the Egyptian Environment - A Theoretical and Field Study". Master Thesis in Accounting, Faculty of commerce, Kafrelsheikh University.

4. Awan, A. \& Saeed, K. (2015), "Relationship between Intellectual Capital and Organizational Performance: A case Study of Public Sector Universities in Southern Punjab-Pakistan". Journal of Resources Development and Management, Vol. 9, p. 35-46.

5. Cabrita, M.R. \& Bontis, N. (2008), "Intellectual capital and business performance in the Portuguese banking industry". International Journal of Technology Management, Vol. 43, No. 13, p. 212-237.

6. Cairns, B., Harris, M., Hutchison, R. \& Tricker, M. (2005), "Improving Performance? The Adoption and Implementation of Quality Systems in U.K. Nonprofits". Nonprofit Management \& Leadership, Vol. 16, Issue 2, p. 135-151.

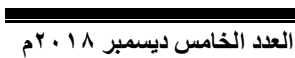


7. Canibano, L. \& Sanchez, P. (2008), "Intellectual Capital Management and Reporting in Universities and Research Institutions". Estudios de Economia Aplicada, Vol. 26, No. 2, p. 7-25

8. De Waal, A.A. (2007), "Is performance management applicable in developing countries? The case of a Tanzanian college". The International Journal of Emerging Markets, Vol. 2, issue 1, p.69-83.

9. De Waal, A.A. \& Counet, H. (2008), "Lessons learned from performance management systems implementations". International Journal of Productivity and Performance Management, Vol.58, No. 4, p. 367-390.

10. Ghazal, R.Y. (2012), "Major Issues in Egyptian Higher Education: Reflections of an Egyptian Student". Comparative \& International Higher Education 4, p. 19-21.

11. Gonzalez-Loureiro, M. \& Teixeira, A. M. (2011), "Intellectual Capital in Public Universities: The Performance- Oriented Approach". International Conference: Proceedings of Managing Services in the Knowledge Economy (MSKE), p. 293-314.

12. Karuhanga, B.N. (2010), "Challenges of performance management in universities in Uganda". Paper presented at the International Research Symposium in Service Management, p. 1-14.

13. Kim, S.J., Yoon, Y.C., Kim, B.H., Lee, B.Y. \& Kang, H.J. (2006), "Knowledge-based Economy and Intellectual Capital: The Impact of National Intellectual and Information Capitals on Economic Growth in Korea". International Journal of Business and Information, Vol. 1, No. 1, p. 28-52.

14. Leitner, K.H. (2002), "Intellectual Capital Reporting for Universities: Conceptual background and application within the reorganization of Austrian universities". Paper prepared for the Conference: The Transparent Enterprise. The Value of Intangibles, Autonomous University of Madrid, Ministry of Economy, p. 1-20.

15. Lu, W.M. (2012). "Intellectual capital and university performance in Taiwan". Economic Modelling, Vol. 29, p. 1081-1089.

16. Mihaiu, D. (2014), "Measuring Performance in The Public Sector: Between Necessity and Difficulty". Studies in Business and Economics Journal, Vol. 9, Issue 2, p. 40-50.

17. Moullin, M. (2007), "Performance Measurement Definitions, Linking Performance Measurement and Organizational Excellence". International Journal of Health Care Quality Assurance, Vol. 20, No. 3, p. 181-183. 
18. Ofori, D. \& Atiogbe, E. (2011), "Strategic planning in public universities: a developing country perspective". Business and Management, Vol. 1, No.7, p. 68-85.

19. Ramirez, Y. \& Gordillo, S. (2014), "Recognition and measurement of intellectual capital in Spanish universities". Journal of Intellectual Capital, Vol. 15, No. 1, p. 173 - 188.

20. Ramirez, Y., Lorduy, C. \& Rojas, J.A. (2007), "Intellectual capital management in Spanish universities". Journal of Intellectual Capital, Vol. 8, No. 4, p. $732-748$.

21. Ramirez, Y., Tejada, A., \& Gordillo, S. (2013), "Recognition of intellectual capital importance in the university sector". International Journal of Business and Social Research, Vol. 3, No. 4, p. 27-41.

22. Ramirez, Y., Tejada, A., \& Manzaneque, M. (2016), " The value of disclosing intellectual capital in Spanish universities", Journal of Organizational Change Management, Vol. 29, No. 2, p. 176- 198.

23. Rashid, S.A. \& Alzaidi, S.H. (2014), "The role of intellectual capital in achieving Superior university performance: An analytical study". Al Qadisiyah Journal of Administrative Sciences and Economics, Vol.16, no. 3, p. 6-40.

24. Sharabati, A.A., Nour, A.I. \& Naser Eddin, Y.A. (2013), "Intellectual Capital Development: A Case Study of Middle East University". Jordan Journal of Business Administration, Vol. 9, No. 3, p. 567-602.

25. Sharafi, M. \& Abbaspour, A. (2013), "Relationship between Intellectual Capital and Function in Universities and Higher Education Institutes". Quarterly of Education Strategies in Medical Sciences, Vol. 6(2), p .75-81.

26. Shehzad, U., Fareed, Z., Zulfiqar, B., Shahzad, F. \& Latif, H.S. (2014), "The Impact of Intellectual Capital on the Performance of Universities". European Journal of Contemporary Education, Vol. 10, No. 4, p. 273-280.

27. Shojaie, S. \& Barani, G. (2013), "Investigating the Effect of Intellectual Capital on Performance of Islamic Azad University of Ghaemshahr Branch, Mazandaran, Iran". International Journal of Basic Sciences \& Applied Research, Vol. 2 (2), pp. 129-132.

28. Spekle, R.F. \& Verbeeten, F.H. (2014), "The use of performance measurement systems in the public sector: Effects on performance", Management Accounting Research, Vol. 25, p. 131-146.

29. State Services Commission (2008), "Performance Measurement Advice and examples on how to develop effective frameworks", Wellington, New Zealand, p.1-68.

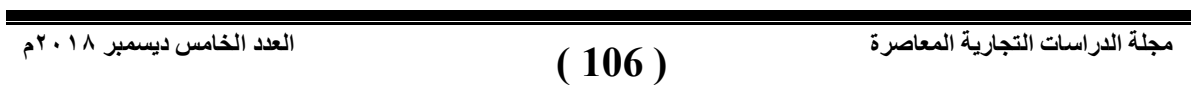


30. Striteska, M. \& Spickova, M. (2012), "Review and Comparison of Performance Measurement Systems". Journal of Organizational Management Studies, Vol. 2012, p.1-13.

31. Taleghani, M., Shirsavar, H.A. \& Gashti, G.B. (2011), "Determine of the relationship between dimensions of intellectual capital and productivity of education organization of Guilan province". Australian Journal of Basic and Applied Sciences, Vol. 5, issue 8, p. $1456-1460$.

32. Wang, X. (2010). "Performance measurement in universities Managerial Perspective". Business Administration - Financial Management, Faculty of Management and Governance, University of Twente, The Netherlands, p.1-88.

33. Wu, H.Y., Chen, J.K. \& Chen, I.S. (2012), "Ways to promote valuable innovation: intellectual capital assessment for higher education system". Qual Quant, Vol. 46, p.1377-1391.

Kafrelsheikh University

Faculty of Commerce

Department of Accounting

\section{Appendix}

\section{Questionnaire List}

Dear Sir

This questionnaire is a part from research entitled "The Role of Intellectual Capital Information in Performance Measurement in Egyptian Governmental universities". And the researchers hope you help them in answering this questionnaire so that they can finish their research.

The researchers confirm that your answer will be used only for the purposes of scientific research.

Yours sincerely,

Prof. Aly Mogahed Ahmed Alsayed

Dr. Ayman Mohamed Sabry Nokhal

Lamees Ameen Mohamed Abdulmajid

First : Personal Data

Name (Optional):

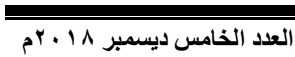

( 107 )

مجلة الدراسات التجارية المعاصرة 
Scientific Qualifications:
$\square \mathrm{BSc}$
Diploma
$\square \mathrm{MSc}$
$\mathrm{PhD}$

\section{Current Situation:}

$\square$ Faculty staff or their assistants

$\square$ Postgraduate students

$\square$ Undergraduate students

Workplace / University:

Years of Experience:
$\square 0-5$
$10-20$
$\square 5-10$
Over 20

Second : Questions of the Questionnaire

Please, tick $(\sqrt{ })$ on front of the level of importance you see suitable for each of the following phrases.

\begin{tabular}{|c|c|c|c|c|c|}
\hline Category & > & 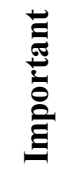 & $\begin{array}{l}\bar{E} \\
\bar{E} \\
\bar{E}\end{array}$ & \& & 艺蒂 \\
\hline
\end{tabular}

First : Importance of using human capital information in measuring performance in universities

1. Announcing the appointment rules of faculty staff and their assistants

2. Ratio of faculty staff to students

3. Ratio of faculty staffs assistants to students

4. Ratio of faculty staff to postgraduate students registered

5. Ratios of the distribution of faculty staff and their assistants on academic 


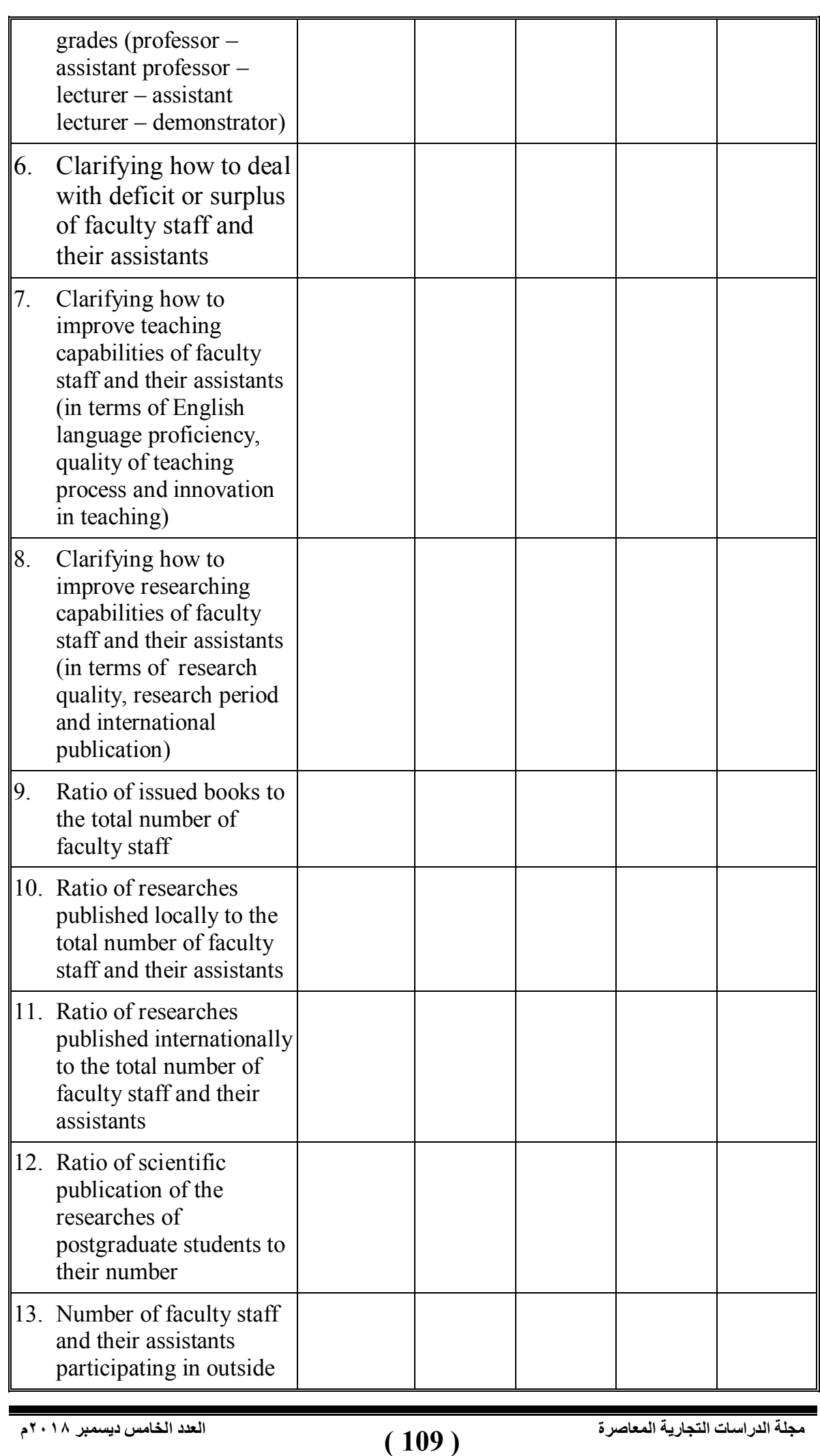




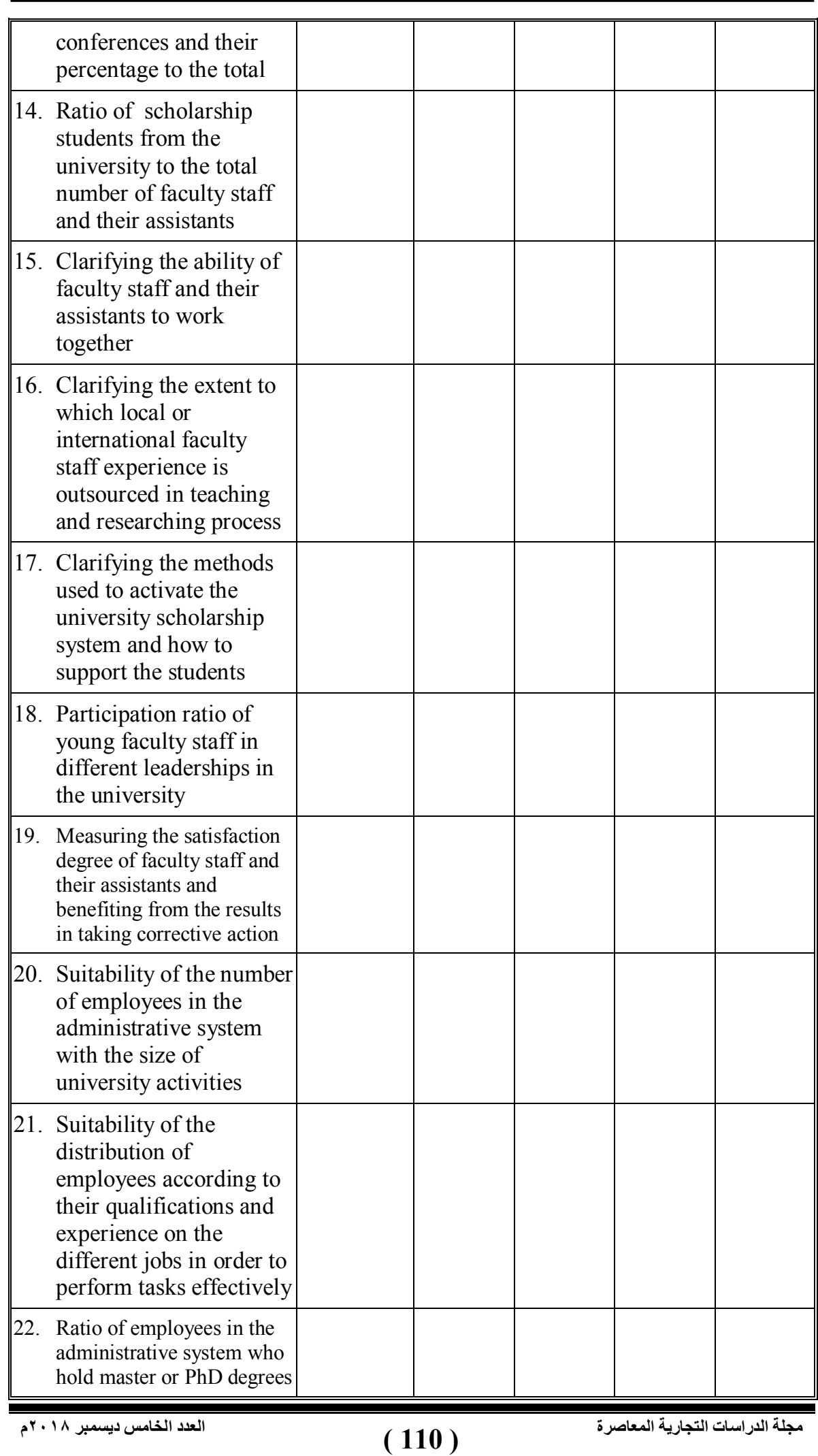




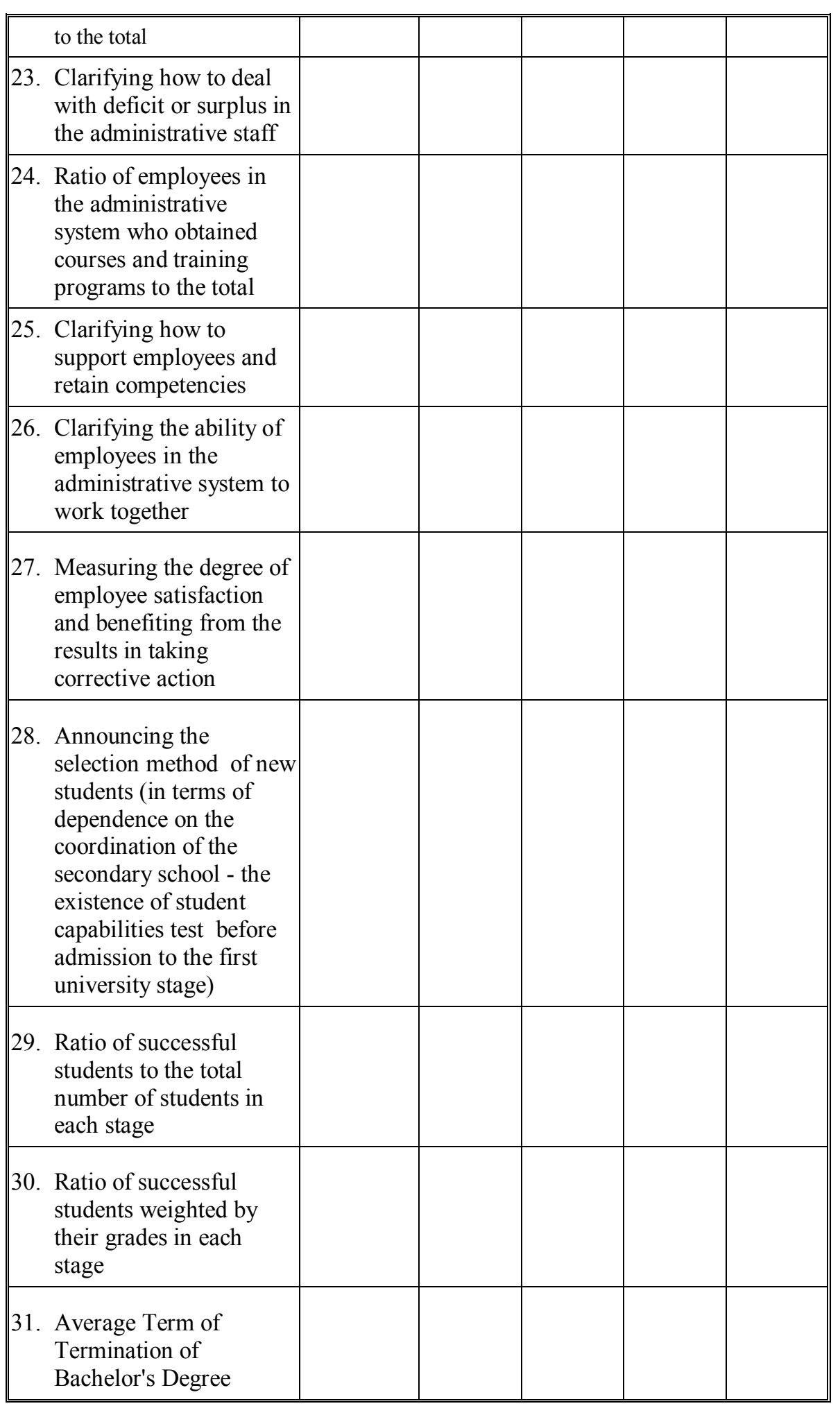

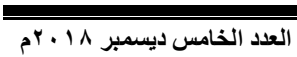




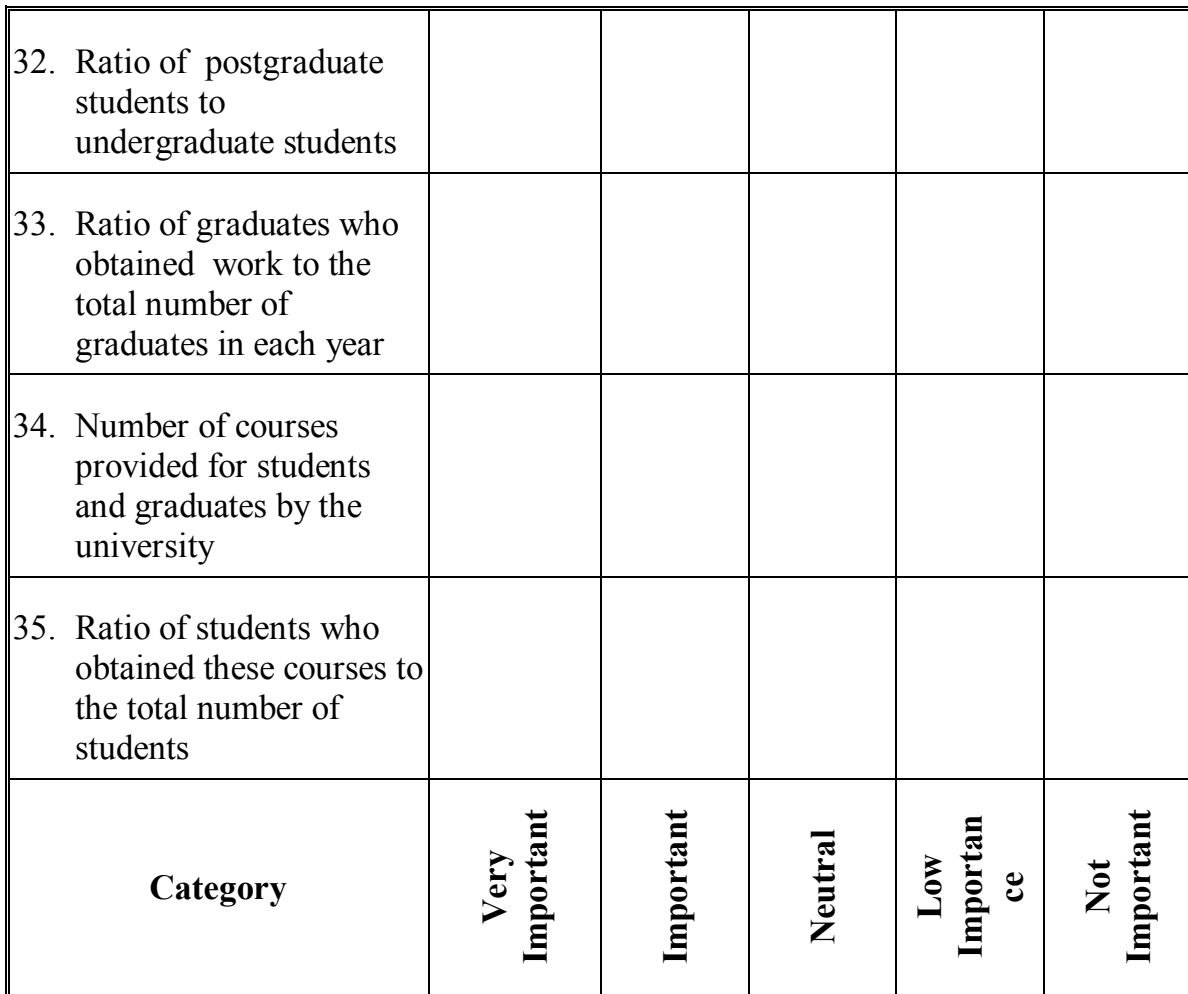

Second : Importance of using structural capital information in measuring performance in universities

1. Clarifying the extent to which educational programs are diversified and their suitability to the needs of society and labor market

2. Clarifying the extent to which postgraduate programs are diversified and their coverage for all disciplines

3. Clarifying the extent to which university education patterns are suitable to the types of provided programs

4. Clarifying the used policies to introduce new educational programs and develop or cancel the existing ones 
5. Announcing the methods used to evaluate students (the student grades through the year, periodic exams, and exam of the first and second semesters)

6. Suitability of the number of appropriate and equipped classrooms to the student numbers

7. Suitability of the number of computers existed in computer labs to the total number of students and researchers

8. Clarifying the extent of the existence and adequacy of the central library in the university (in terms of availability of books, references, equipment and services that meet the needs of students and researchers)

9. Clarifying the extent of the existence and adequacy of the digital library to those concerned

10. Clarifying the extent to which a scientific research plan is existed and its suitability with the available resources and the extent to which mechanisms are existed to follow up its implementation

11. Clarifying the extent to which policies and mechanisms are existed to support scientific research, stimulating it, and improving researchers capabilities 


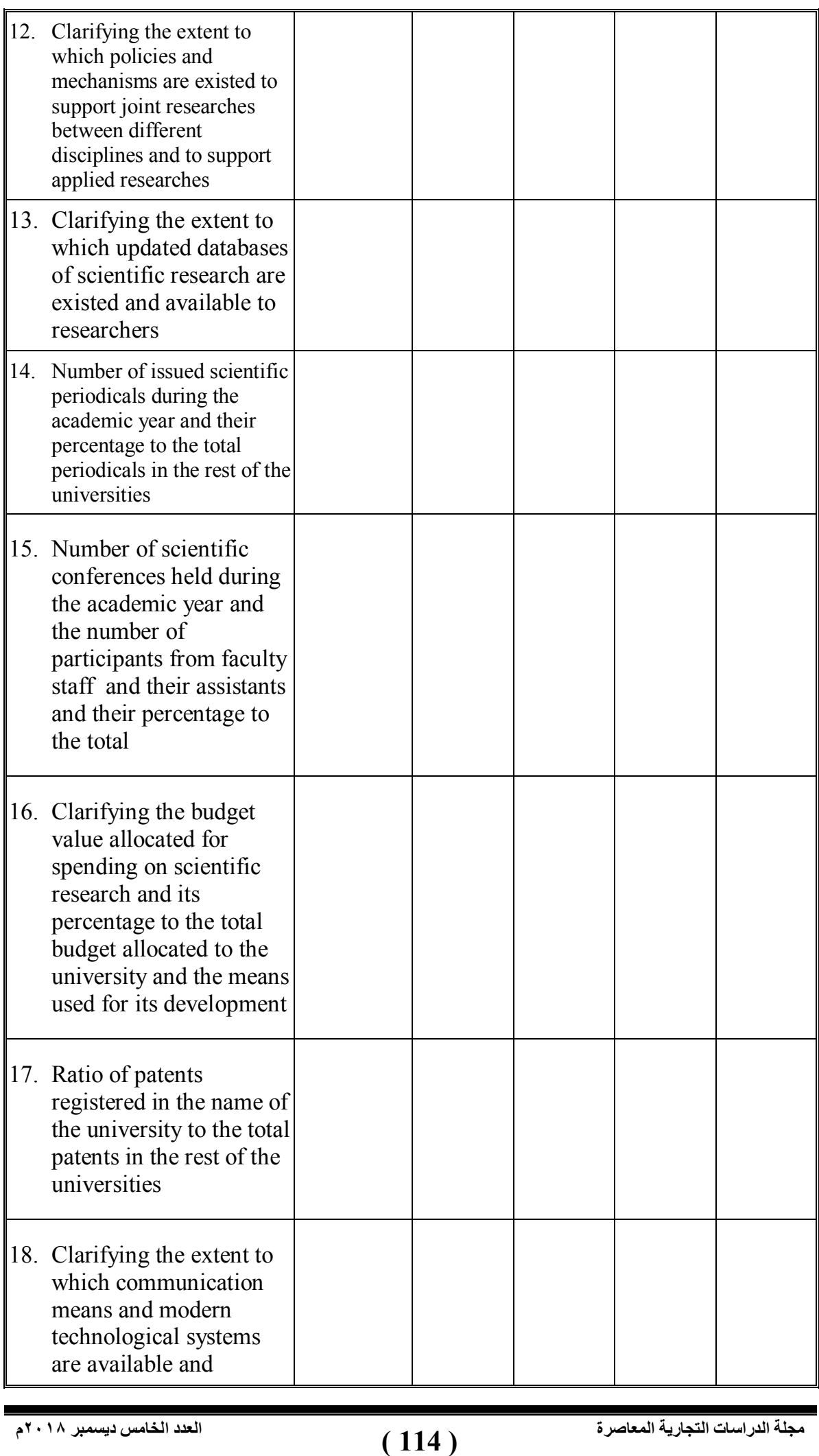


suitable to the academic,

research, and

administrative activity

19. Clarifying the extent to which suitable offices are available for faculty staff and their assistants

20. Clarifying the extent to which a website of the university is existed with diversified information and services and periodically updated to serve all parties concerned

\begin{tabular}{|c|c|c|c|c|c|}
\hline Category & 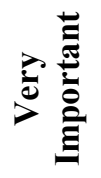 & 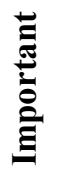 & 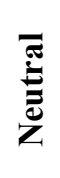 & 㿣 & Z气 \\
\hline
\end{tabular}

Third: Importance of using relational capital information in measuring performance in universities

1. Clarifying the extent of the relationship strength between faculty staff, students, researchers, and graduates

2. Clarifying the mechanisms used by the university to encourage outstanding students through the financial return (reward of excellence) and moral (honoring at graduation ceremonies)

3. Number of courses provided by different Egyptian bodies within universities

4. Clarifying the extent to which these courses 


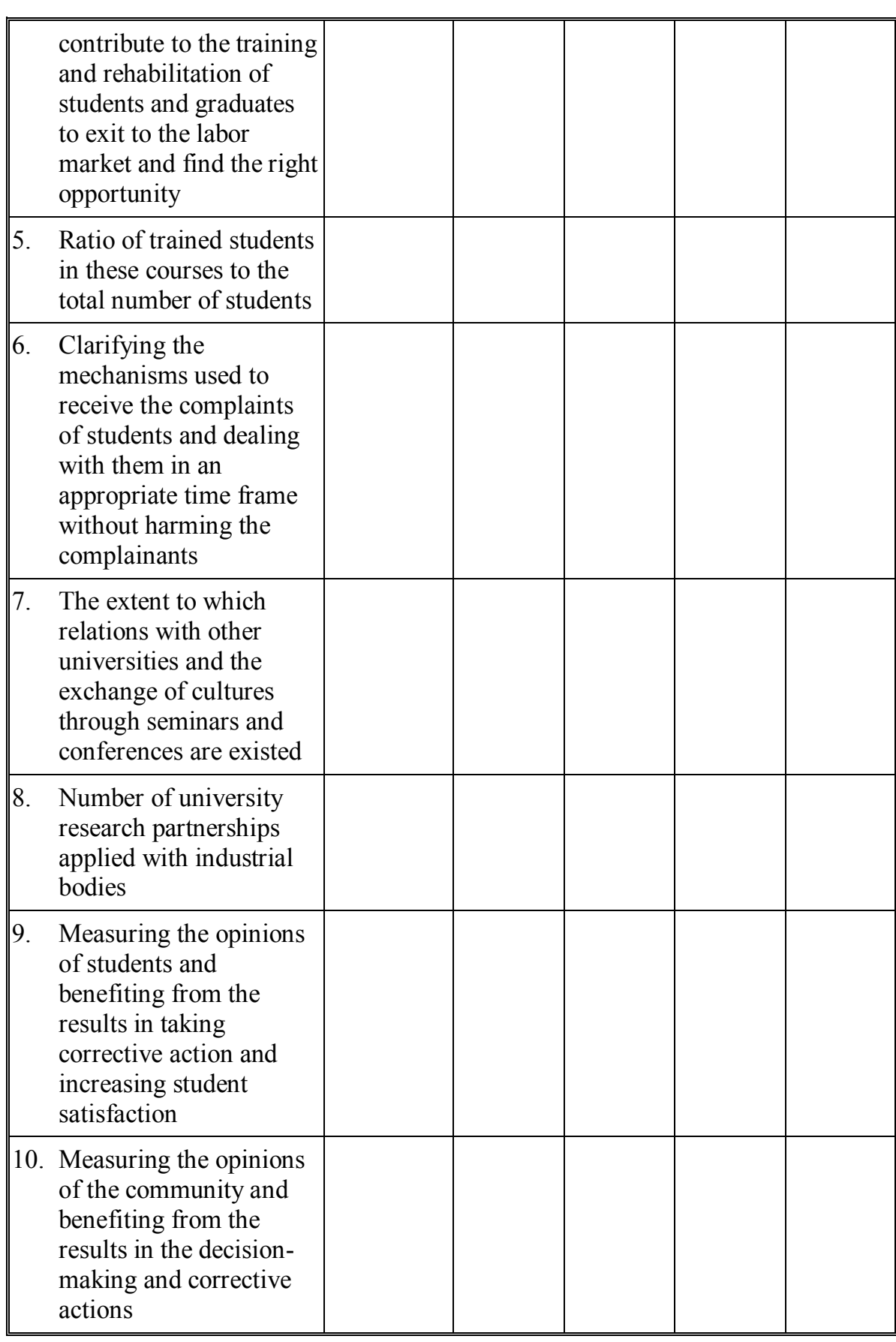

1. Intellectual capital disclosure for universities has become mandatory in some countries, so what is your opinion about the importance of obligating Egyptian governmental universities to disclose their intellectual capital information?

○ Important - disclose 
○ Not important - not disclose

2. If Egyptian governmental universities disclose their intellectual capital information, will this disclosure affect the performance measurement process?

○ Yes

3. If Egyptian governmental universities disclose their intellectual capital information, will this disclosure contribute to improving the performance of the universities?

○ Yes

O No

In the case of any suggestions or observations on the questionnaire, please mention them in details to benefit from your views. 